\title{
KEBIJAKAN PERLINDUNGAN LAHAN PERTANIAN PANGAN BERKELANJUTAN DALAM DIMENSI POLITIK HUKUM PENATAAN RUANG
}

\author{
POLICY FOR THE PROTECTION OF SUSTAINABLE \\ AGRICULTURAL LAND IN THE POLITICAL DIMENSIONS OF \\ SPATIAL PLANNING LAW
}

\author{
Endang Dyah Ayu Pitaloka \\ Universitas Pembangunan Nasional Veteran Jakarta \\ E-mail: endang.dapitaloka@gmail.com
}

\begin{abstract}
This paper aims to explain the concept and analyze the implementation of sustainable agricultural food protection policies in Indonesia. This is inseparable from the problem of the conversion of agricultural land to non-agriculture which continues to occur. These problems are not in accordance with Act No. 41 of 2009, which aims to guarantee the right to food as a basic right of every citizen and also wants to realize the independence, resilience, and food sovereignty as well as the welfare of farmers, especially the weak. This research is a normative legal research with legislation and analytical approach and information technology approach. The results of this research concluded that sustainable agricultural land protection policies cannot stand alone because they depend heavily on regulatory support in the field of spatial planning. It was also concluded that the implementation of sustainable agricultural food protection policies in Indonesia contained in regional regulations regarding spatial planning is still very low due to various factors that influence it, especially the political factors of regional authorities who are less concerned with this policy.
\end{abstract}

Keywords: Sustainable Food Agriculture Land, Politics of Law, Spatial Planning

\begin{abstract}
Abstrak
Tulisan ini bertujuan untuk menjelaskan konsep dan menganalisis implementasi kebijakan perlindungan lahan pertanian pangan berkelanjutan di Indonesia. Hal ini tidak terlepas dari permasalahan alih fungsi lahan pertanian menjadi nonpertanian yang terus menerus terjadi. Permasalahan tersebut tidak sesuai Undang-Undang Nomor 41 Tahun 2009, yang bertujuan untuk menjamin hak atas pangan sebagai hak asasi setiap warga negara dan juga ingin mewujudkan kemandirian, ketahanan, dan kedaulatan pangan sekaligus mensejahterakan para petani terutama yang lemah. Penelitian ini adalah penelitian hukum normatif dengan pendekatan perundangundangan dan pendekatan analitis serta pendekatan teknologi informasi. Hasil penelitian ini menyimpulkan bahwa kebijakan perlindungan lahan pertanian pangan berkelanjutan tidak dapat berdiri sendiri karena sangat bergantung pada dukungan peraturan di bidang penataan ruang. Disimpulkan juga bahwa implementasi kebijakan perlindungan lahan pertanian pangan berkelanjutan di Indonesia yang dimuat dalam peraturan daerah mengenai rencana tata ruang masih sangat rendah dikarenakan berbagai faktor yang mempengaruhinya terutama faktor politik penguasa daerah yang kurang peduli dengan kebijakan ini.
\end{abstract}

Kata Kunci: Lahan Pertanian Pangan Berkelanjutan, Politik Hukum, Tata Ruang 


\section{PENDAHULUAN}

Kebijakan perlindungan lahan pertanian pangan berkelanjutan diadakan oleh Negara untuk menjamin hak atas pangan sebagai hak asasi setiap warga negara dan juga ingin mewujudkan kemandirian, ketahanan, dan kedaulatan pangan sekaligus mensejahterakan para petani terutama yang lemah. Namun semenjak kebijakan ini mulai digulirkan pada tahun 2009 tampaknya sampai saat ini belum terdengar sama sekali cerita sukses yang diraih sehingga perlu dipertanyakan keseriusan (political will) para penguasa di negeri ini dalam mengemban amanah yang diperintahkan Undang-Undang Nomor 41 Tahun 2009 tentang Perlindungan Lahan Pertanian Pangan Berkelanjutan.

Landasan konstitusional Undang-Undang Nomor 41 Tahun 2009 bersumber pada Pasal 33 ayat (3) UUD 1945 yang menyatakan bahwa "Bumi dan air dan kekayaan alam yang terkandung di dalamnya dikuasai oleh negara dan dipergunakan untuk sebesar-besar kemakmuran rakyat". Lebih lanjut undang-undang ini juga merupakan implementasi-an dari Pasal 48 ayat (2) Undang-Undang Nomor 26 Tahun 2007 tentang Penataan Ruang. ${ }^{1}$ Dengan demikian, ketika membahas kebijakan perlindungan lahan pertanian pangan berkelanjutan sudah barang tentu harus berangkat dari kerangka berpikir yang ditujukan bagi sebesar-besar kemakmuran rakyat dan harus pula melihat penjabarannya secara komprehensif dalam dimensi hukum penataan ruang.

Munculnya gagasan perlindungan lahan pertanian tidak terlepas dari prakarsa Komisi IV Dewan Perwakilan Rakyat Republik Indonesia. Komisi IV berpandangan bahwa sektor pertanian memiliki peran yang sangat strategis dalam perekonomian nasional melalui sumbangannya terhadap Produk Domestik Bruto (PDB), perolehan devisa, penyediaan pangan dan bahan baku industri, pengentasan kemiskinan, penyediaan lapangan kerja dan peningkatan pendapatan masyarakat. Selain memberikan kontribusi langsung, sektor pertanian juga memiliki kontribusi tidak langsung berupa efek pengganda yaitu keterkaitan input output antar industri, konsumsi, dan investasi yang juga cukup besar. Selain itu, pertanian juga merupakan sektor yang tangguh sehingga dapat diandalkan sebagai penyangga pembangunan nasional. Pada masa krisis ekonomi, sektor pertanian terbukti lebih tangguh dan mampu bertahan serta pulih lebih cepat dibandingkan sektor lain. Pada tahun 1997/1998, perekonomian nasional menurun sebesar 13,13 persen, sementara sektor pertanian hanya menurun 0,74 persen. $^{2}$

Namun permasalahan yang dihadapi pada saat gagasan Komisi IV digulirkan adalah tingginya tekanan terhadap lahan pertanian. ${ }^{3}$ Dengan peningkatan jumlah penduduk sekitar 1,34 persen per tahun, sementara luas lahan yang ada relatif tetap, telah menyebabkan terjadinya peningkatan tekanan terhadap sumber daya lahan dan air terutama di Jawa. Sebagai gambaran, luas rata-rata kepemilikan lahan sawah di Jawa dan Bali hanya 0,34 hektar per rumah tangga petani. Selain makin menyempitnya ratarata penguasaan lahan oleh petani, terjadi juga persaingan yang tidak seimbang dalam penggunaan lahan, terutama antara sektor pertanian dan nonpertanian. Keadaan yang demikian mengakibatkan meningkatnya laju besaran konversi atau alih fungsi lahan

${ }^{1}$ Lihat Penjelasan Umum Undang-Undang Nomor 41 Tahun 2009. Dalam Penjelasan Umum Undang-Undang Nomor 41 Tahun 2009 antara lain ditegaskan bahwa Undang-Undang Nomor 26 Tahun 2007 tentang Penataan Ruang memerintahkan perlunya perlindungan terhadap kawasan lahan abadi pertanian pangan yang pengaturannya dengan undang-undang.

${ }^{2}$ Sekretariat Jenderal Dewan Perwakilan Rakyat Indonesia, 2012, Proses Pembahasan Rancangan Undang-Undang tentang Perlindungan Lahan Pertanian Pangan Berkelanjutan Buku 1, Sekretariat Jenderal Dewan Perwakilan Rakyat Indonesia, Jakarta, hlm. 6.

${ }^{3}$ Lihat Maria S.W. Sumardjono, 2009, Tanah Dalam Perspektif Hak Ekonomi, Sosial dan Budaya, Penerbit Buku Kompas, Jakarta, hlm. 4.

50 Jurnal IUS Kajian Hukum dan Keadilan 
pertanian dari tahun ke tahun. Konversi lahan sawah menjadi lahan nonpertanian dari tahun 1999 s/d 2002 diperkirakan mencapai 330.000 hektar atau setara dengan 110.000 hektar per tahun. ${ }^{4}$

Dikemukakan juga bahwa selama ini berbagai kebijaksanaan yang berkaitan dengan masalah pengendalian alih fungsi lahan pertanian, terutama sawah sudah banyak dibuat. Namun demikian, implementasinya tidak efektif karena tidak didukung oleh data dan sikap proaktif yang memadai dari pemangku kepentingan. Selain itu dampak negatif konversi lahan sawah tidak dianggap sebagai persoalan yang perlu ditangani secara serius dan konsisten. Kompetensi untuk melakukan pengendalian alih fungsi lahan sawah masih rendah, karena belum adanya suatu aturan baku yang dapat memayungi seluruh upaya pengendalian yang dilakukan dan perlindungan terhadap lahan pertanian produktif yang ada. Oleh karena adanya berbagai masalah tersebut maka atas usul inisiatif Komisi IV Dewan Perwakilan Rakyat Republik Indonesia diterbitkanlah Undang-Undang Nomor 41 Tahun 2009. ${ }^{5}$

Meskipun Undang-Undang Nomor 41 Tahun 2009 telah diterbitkan dan dalam materi muatannya dimuat sanksi administratif dan bahkan sanksi pidana bagi pihakpihak yang berani mengalihfungsikan lahan pertanian, namun sampai tulisan ini dibuat masih banyak pemberitaan di berbagai media yang mengangkat isu alih fungsi lahan pertanian. Diantaranya dapat dikemukakan bahwa alih fungsi lahan pertanian menjadi lahan nonpertanian di Bali selama sepuluh tahun terakhir telah mengorbankan ratarata 1.000 hektar setiap tahunnya. ${ }^{6}$ Begitu pula di Daerah Istimewa Yogyakarta, lahan pertanian produktif setiap tahunnya berkurang seluas lebih dari 250 hektar per tahun. ${ }^{7}$ Di daerah timur Indonesia pun tepatnya di Lembor, Kabupaten Manggarai Barat, Nusa Tenggara Timur tidak luput dari kegiatan alih fungsi lahan pertanian sehingga Pemerintah Provinsi Nusa Tenggara Timur mengancam akan menggusur Perumahan di Lahan Pertanian. ${ }^{8}$ Namun ketika disatu sisi terdapat pihak pemerintah yang hendak mempertahankan keberadaan lahan pertanian seperti di Nusa Tenggara Timur, disatu sisi terdapat pula sikap bertentangan yang mengganggap perlindungan lahan pertanian kurang penting bagi mereka seperti sikap Dewan Perwakilan Rakyat Daerah Kabupaten Bekasi yang membekukan Rancangan Peraturan Daerah tentang Lahan Pertanian Pangan Berkelanjutan. ${ }^{9}$ Hal yang serupa juga terlihat dari sikap Kepala Dinas Pekerjaan Umum dan Penataan Ruang Kabupaten Kudus yang lebih mengutamakan area baru untuk pemukiman dan pengembangan usaha dengan upaya mengusulkan revisi lahan pertanian pangan berkelanjutan dalam rencana tata ruang setempat. ${ }^{10}$ Apabila hal yang disebut terakhir ini terjadi maka perlu diambil tindakan tegas oleh aparat penegak hukum karena tidak dikenal revisi lahan pertanian pangan berkelanjutan untuk pemukiman dan pengembangan usaha. Alih fungsi lahan pertanian pangan berkelanjutan hanya

\footnotetext{
${ }^{4}$ Sekretariat Jenderal Dewan Perwakilan Rakyat Indonesia, Op. cit., hlm. 7.

${ }^{5}$ Ibid., hlm. 9-10.

${ }^{6}$ Kompas, Mengkhawatirkan! Alih Fungsi Lahan Pertanian, https://nasional.kompas.com/read/2009/06/08/09585932/ mengkhawatirkan.alih.fungsi.lahan.pertanian. diakses pada tanggal 10 oktober 2019.

${ }^{7}$ Silvy Dian Setiawan, Alih Fungsi Lahan di DIY Capai 250 Hektare per Tahun, https://www.republika.co.id/berita/nasional/daerah/19/03/13/poasot370-alih-fungsi-lahan-di-diy-capai-250-hektare-per-tahun. diakses pada tanggal 10 oktober 2019.

${ }^{8}$ Palce Amalo, Pemprov NTT Ancam Gusur Perumahan di Lahan Pertanian, https://www.mediaindonesia.com/read/detail/257772-pemprov-ntt-ancam-gusur-perumahan-di-lahan-pertanian. diakses pada tanggal 10 oktober 2019.

${ }^{9}$ Tommi Andryandy, Raperda Dibekukan, Potensi Alih Fungsi di Kabupaten Bekasi Makin Terbuka, https://www.pikiranrakyat.com/jawa-barat/2019/07/23/raperda-dibekukan-potensi-alih-fungsi-di-kabupaten-bekasi-makin-terbuka. diakses pada tanggal 10 oktober 2019.

${ }_{10}$ Anton WH, Revisi LP2B Tak Matikan Pertanian, https://www.suaramerdeka.com/smcetak/baca/83750/revisi-lp2b-tak-matikan-pertanian. diakses pada tanggal 10 oktober 2019.
} 
dimungkinkan dalam dua hal yaitu "kepentingan umum" atau "bencana alam", itupun diatur dengan persyaratan yang ketat sebagaimana yang ditentukan oleh UndangUndang Nomor 41 Tahun 2009.

Pertanyaan yang muncul kemudian apakah isu alih fungsi lahan pertanian adalah isu hukum atau bukan? Jawaban terhadap pertanyaan tersebut penting diuraikan agar nantinya siapa saja yang membaca tulisan ini dapat menilai apakah tulisan ini membahas isu hukum atau bukan. Alih fungsi lahan pertanian mungkin saja bukan merupakan suatu isu hukum dikarenakan rencana tata ruang baik ditingkat pusat, provinsi dan kabupaten/kota tidak satu pun menentukan rencana peruntukan pertanian pada suatu area tertentu meskipun berada pada lahan sawah. Akan tetapi berbeda halnya bilamana peraturan tata ruang tingkat pusat, provinsi dan kabupaten/kota menentukan suatu area untuk direncanakan sebagai peruntukan pertanian. Dalam hal yang disebutkan terakhir ini, ketika terjadi alih fungsi lahan pertanian yang berada dalam rencana peruntukan pertanian berdasarkan peraturan tata ruang, tentu menjadi isu hukum yang perlu dipersoalkan. Dengan demikian, alih fungsi lahan pertanian yang dilakukan pada rencana peruntukan pertanian tidak sesuai dengan hukum negara dan harus ditindak oleh aparat penegak hukum.

Dalam upaya memahami lebih lanjut mengenai permasalahan alih fungsi lahan pertanian maka ada baiknya disajikan beberapa koordinat yang diolah berdasarkan pendekatan teknologi informasi. Namun sebelum menunjukkan beberapa koordinat yang telah diolah, penulis terlebih dulu memasukkan kata kunci "Meikarta" pada tautan Google Maps. Langkah ini menghasilkan satu koordinat yang mendekati letak pembangunan Meikarta yaitu longitude 107.1619083 dan latitude -6.3354451. Berikut ini tampilan citra satelit disekitar area pembangunan Meikarta.

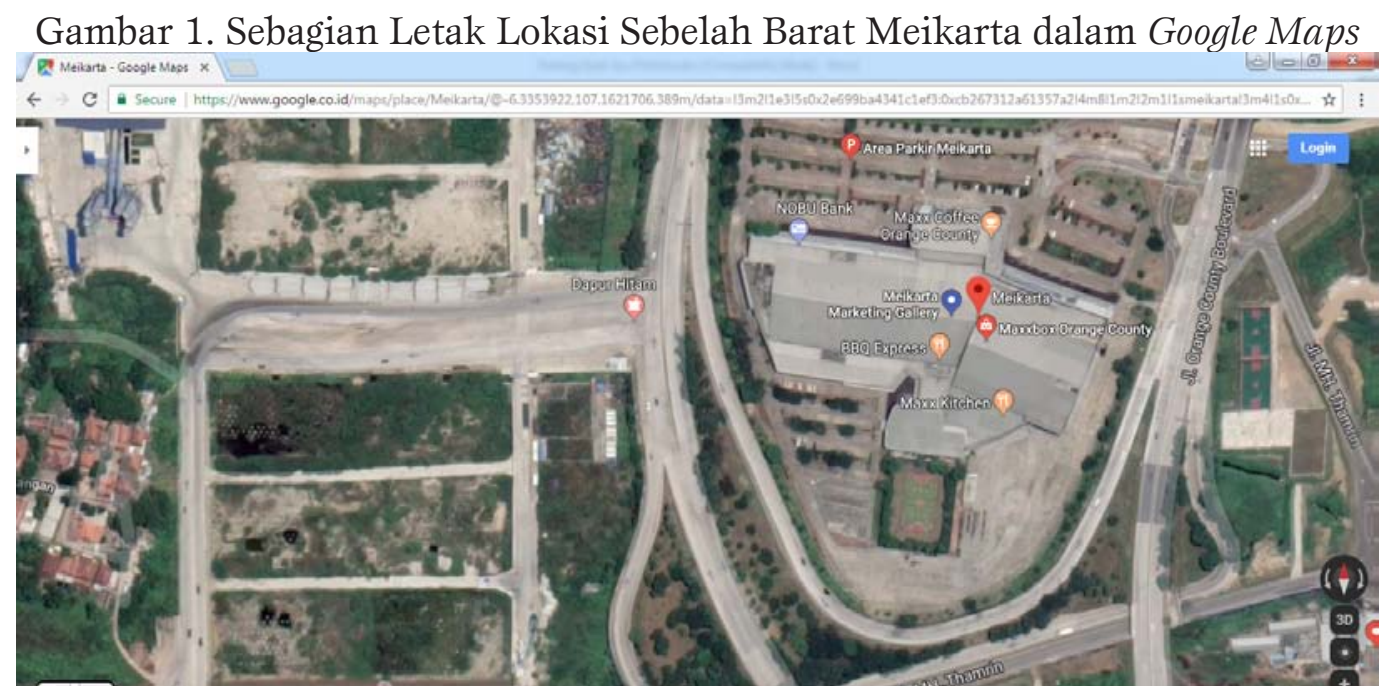

Sumber: https://www.google.co.id/maps, diakses pada tanggal 7 Oktober 2019.

Berdasarkan koordinat yang diperoleh di atas, maka perlu diteliti sebagian area sebelah barat Meikarta yang berada pada kotak berwarna merah. Hal yang diteliti yaitu apa penggunaan lahan dimasa lampau? Dan apa saja rencana tata ruang yang telah ditentukan oleh hukum di area kotak berwarna merah? Koordinat di area kotak berwarna merah tersebut diolah menggunakan aplikasi sistem informasi geografis yang disebar menjadi empat titik yaitu:

1. Longitude 107.1594470 dan Latitude -6.3327620

52 Jurnal IUS Kajian Hukum dan Keadilan 
2. Longitude 107.1612460 dan Latitude -6.3327620

3. Longitude 107.1612600 dan Latitude -6.3367020

4. Longitude 107.1595190 dan Latitude -6.3367160

Bilamana koordinat di atas dimasukkan dalam aplikasi Google Earth maka dapat terlihat bahwa pada tahun 2012 area kotak berwarna merah merupakan lahan pertanian seperti gambar di bawah ini.

Gambar 2. Penggunaan Lahan Pada Tahun 2012 di Sebagian Area Sebelah Barat Meikarta

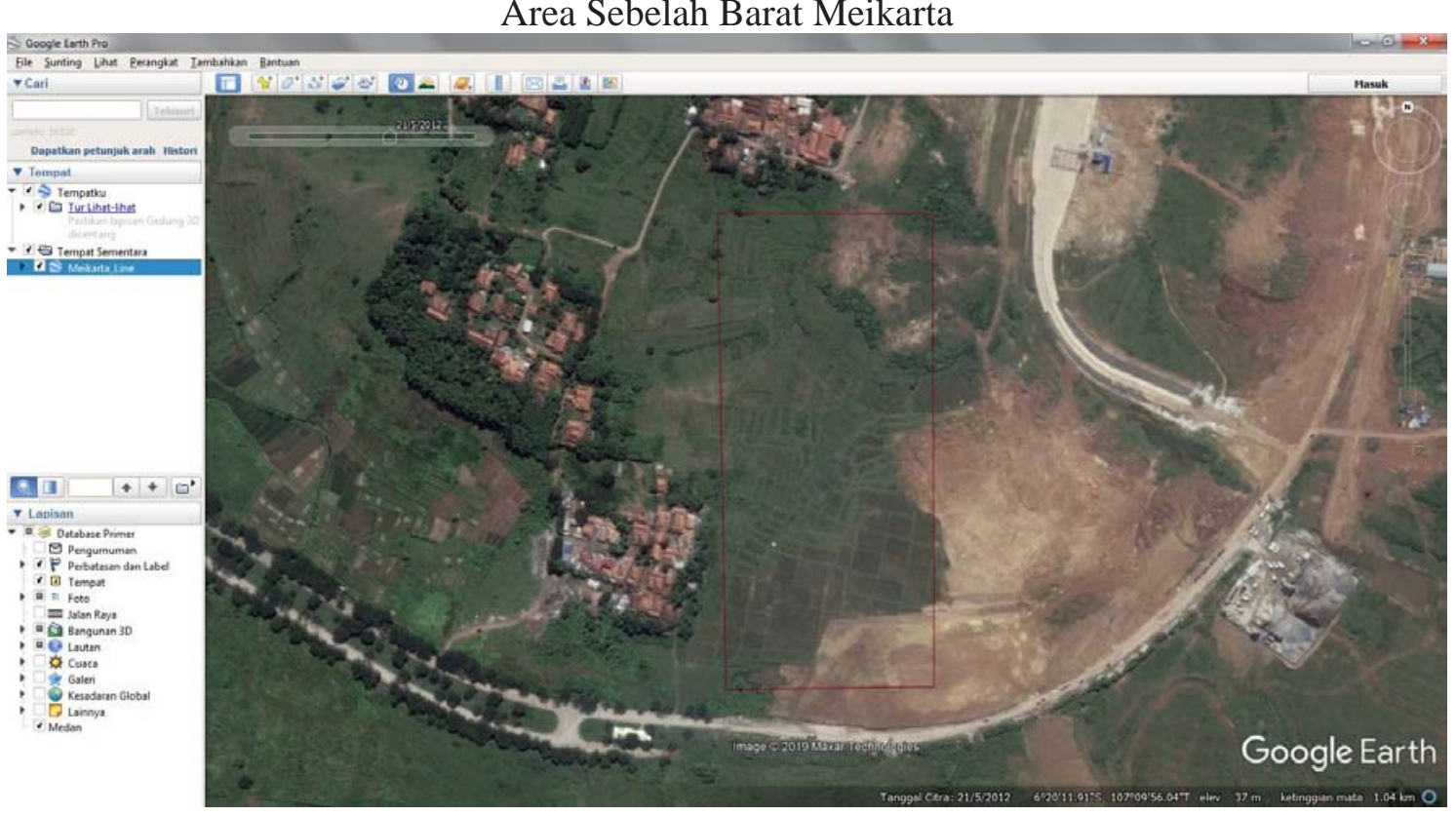

Sumber: Aplikasi Google Earth, diakses pada tanggal 7 Oktober 2019.

Kemudian empat koordinat tersebut perlu dimasukkan juga kedalam aplikasi Gistaru http://gistaru.atrbpn.go.id/rtronline/ yang mana hasilnya dapat dilihat pada gambargambar yang disajikan di bawah ini.

Gambar 3. Rencana Tata Ruang Nasional di Sebagian Area Sebelah Barat Meikarta (Pertanian Tanaman Pangan Lahan Basah/Lahan Kering)

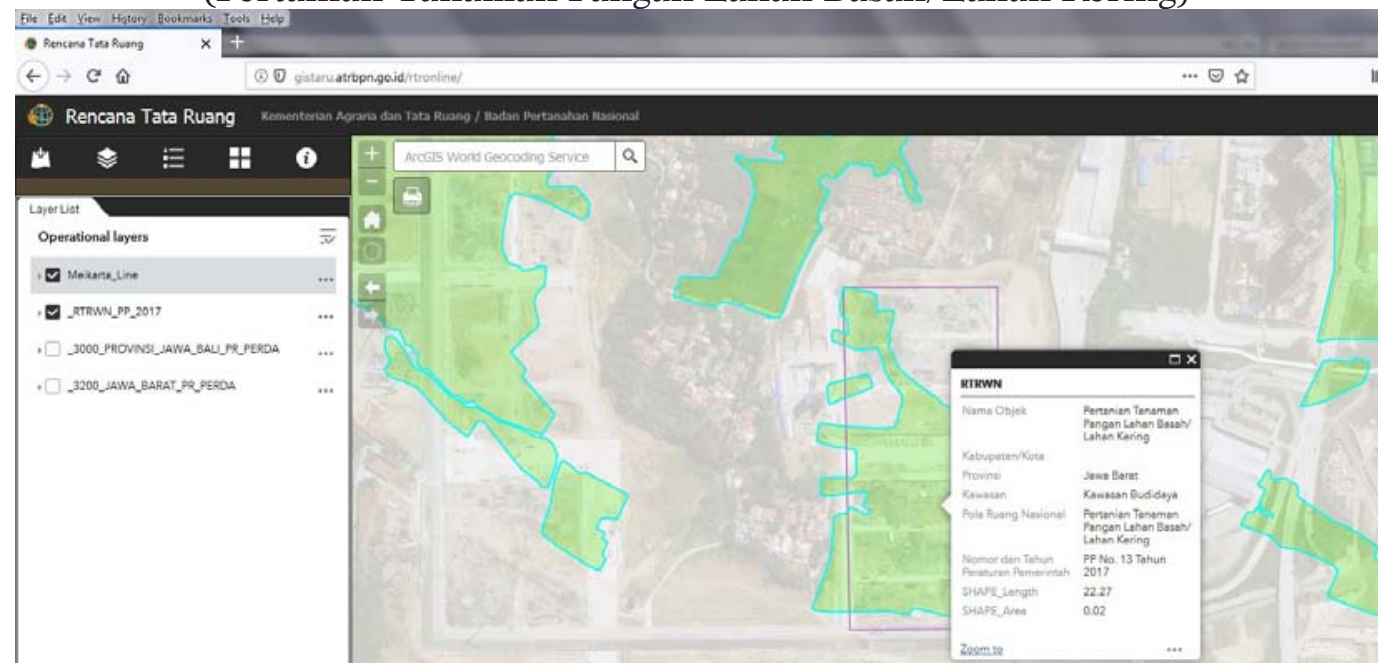

Sumber: http://gistaru.atrbpn.go.id/rtronline/, diakses pada tanggal 7 Oktober 2019. 
Kotak berwarna merah pada gambar 3 di atas letaknya sama dengan gambar 2, yang mana kemudian kotak tersebut didudukan pada pola ruang rencana tata ruang nasional berdasarkan Peraturan Pemerintah Nomor 13 Tahun 2017. Dapat dilihat bahwa kotak merah yang didudukan dalam pola ruang nasional ini berada pada "Pertanian Tanaman Pangan Lahan Basah/Lahan Kering".

Gambar 4. Rencana Tata Ruang Nasional di Sebagian Area Sebelah Barat Meikarta

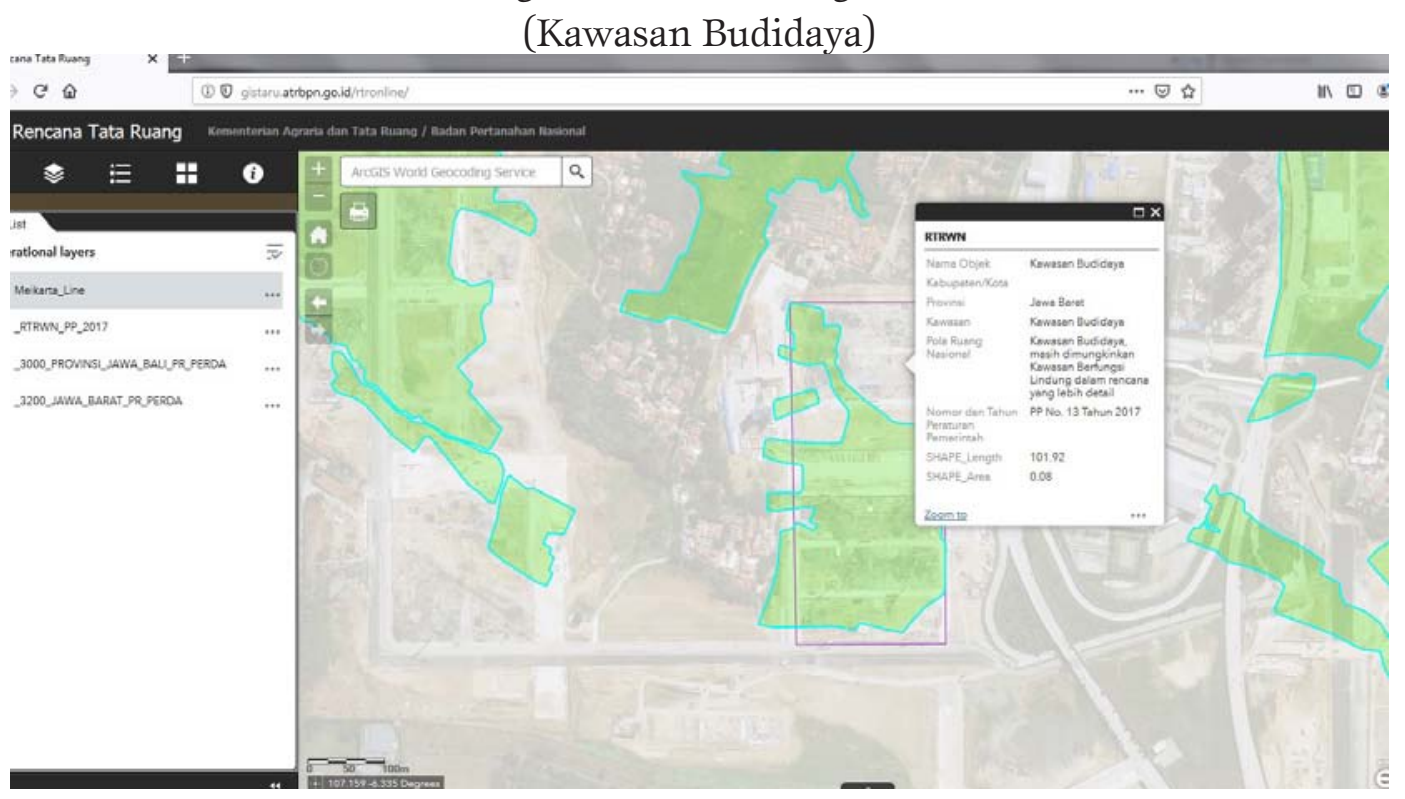

Sumber: http://gistaru.atrbpn.go.id/rtronline/, diakses pada tanggal 7 Oktober 2019.

Dalam gambar 4, kotak berwarna merah masih didudukan pada pola ruang rencana tata ruang nasional berdasarkan Peraturan Pemerintah Nomor 13 Tahun 2017. Dapat dilihat bahwa kotak merah yang didudukan dalam pola ruang nasional ini berada pada "Kawasan Budidaya".

Dengan demikian, kotak berwarna merah dalam gambar 3 dan gambar 4 berada pada sebagian "Pertanian Tanaman Pangan Lahan Basah/Lahan Kering" dan sebagian lagi berada pada "Kawasan Budidaya".

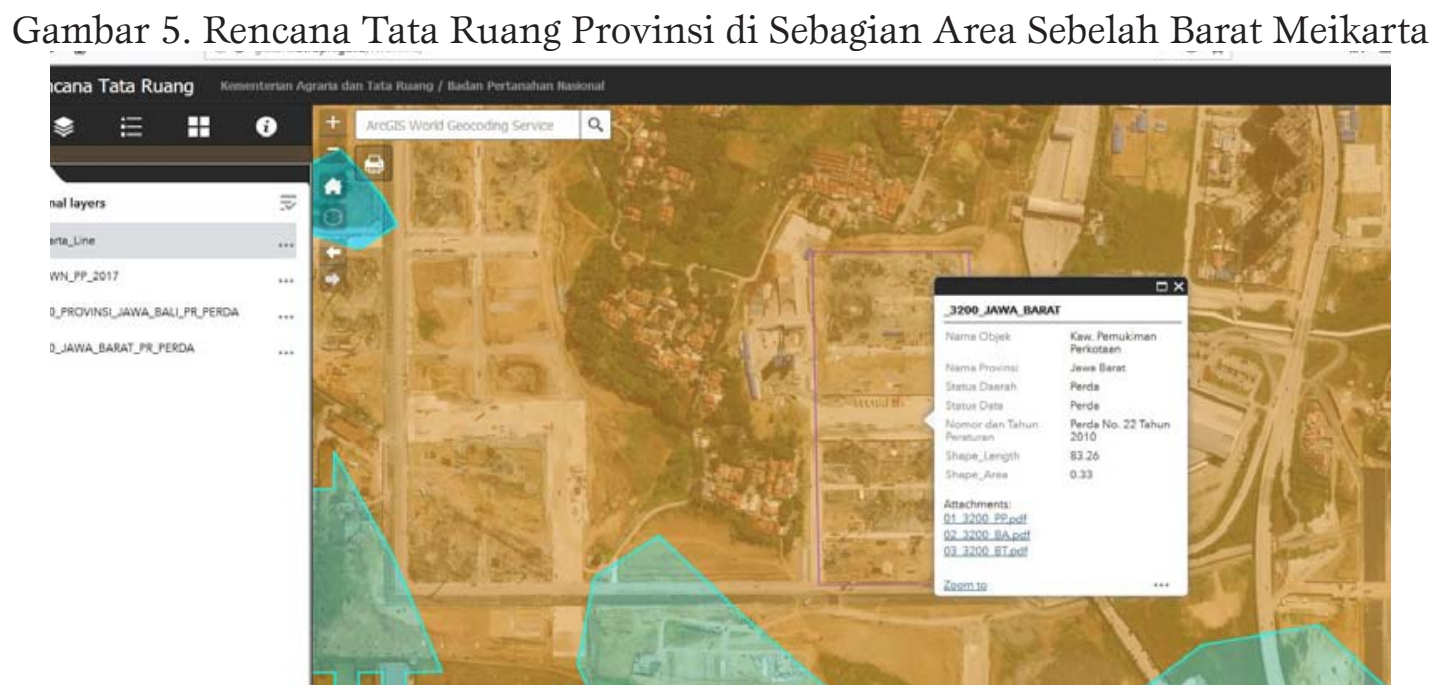

Sumber: http://gistaru.atrbpn.go.id/rtronline/, diakses pada tanggal 7 Oktober 2019. 
Selanjutnya jika kotak berwarna merah ditinjau dari Peraturan Daerah Provinsi Jawa Barat Nomor 22 Tahun 2010 maka area sebagaimana kotak dalam gambar 5 di atas berada pada "Kawasan Permukiman Perkotaan".

Gambar 6. Rencana Tata Ruang Kabupaten di Sebagian Area Sebelah Barat Meikarta

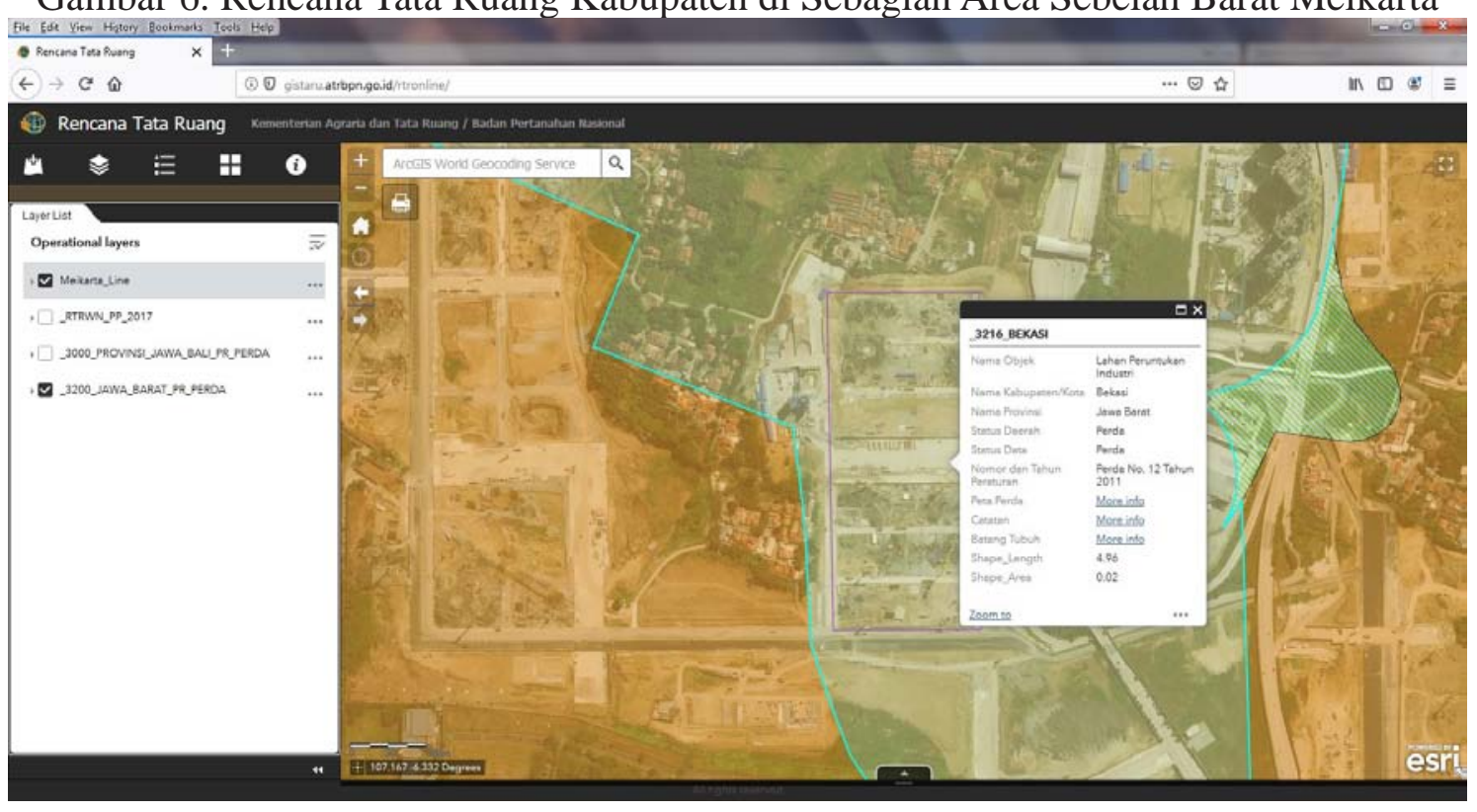

Sumber: http://gistaru.atrbpn.go.id/rtronline/, diakses pada tanggal 7 Oktober 2019.

Bilamana kotak berwarna merah didudukan dalam Peraturan Daerah Kabupaten Bekasi Nomor 12 Tahun 2011 maka telihat bahwa area tersebut berada pada "Lahan Peruntukan Industri" sebagaimana disajikan dalam gambar 6 .

Dari paparan gambar 3 sampai dengan gambar 6 di atas terlihat jelas bahwa adanya ketidaksinkronan penentuan rencanatata ruangyang dimuatdalam Peraturan Pemerintah Nomor 13 Tahun 2017, Peraturan Daerah Provinsi Jawa Barat Nomor 22 Tahun 2010, dan Peraturan Daerah Kabupaten Bekasi Nomor 12 Tahun 2011. Ketidaksinkronan itu dikarenakan masing-masing peraturan berbeda-beda dalam mengarahkan peruntukan pada area kotak berwana merah, yang rinciannya dapat disimak sebagai berikut:

1. Peraturan Pemerintah mengarahkan sebagian "Pertanian Tanaman Pangan Lahan Basah/Lahan Kering" dan sebagian "Kawasan Budidaya".

2. Peraturan Daerah Provinsi mengarahkan sebagai "Kawasan Permukiman Perkotaan". 3. Peraturan Daerah Kabupaten mengarahkan sebagai "Lahan Peruntukan Industri".

Berdasarkan uraian dimuka maka dapat dikatakan bahwa alih fungsi lahan pertanian yang terjadi di sebagian area empat koordinat sebelah barat Meikarta itu sangatlah rumit jika dikaji dari aspek hukum. Dapat dicermati bahwa peraturan-peraturan di atas menunjukkan irisan yang tidak seiring sejalan sehingga menimbulkan ketidakpastian hukum. Bilamana dihubungkan dengan teori Hans Kelsen tentang jenjang norma (stufentheorie), seharusnya peraturan yang rendah tidak boleh bertentangan dengan peraturan yang lebih tinggi kedudukannya. ${ }^{11}$ Akan tetapi dalam penerapannya terlihat bahwa peraturan yang terendahlah yang digunakan untuk menerbitkan izin lokasi karena memang lebih operasional. Lantas apa maknanya jika peraturan yang lebih tinggi

${ }^{11}$ Lihat Maria Farida Indrati Soeprapto, 1998, Ilmu Perundang-Undangan, Penerbit Kanisius, Yogyakarta, hlm. 39. Lihat juga Undang-Undang Nomor 12 Tahun 2011 tentang Pembentukan Peraturan Perundang-Undangan, Pasal 7 dan penjelasannya. 
tidak diacu oleh peraturan yang lebih rendah? Dalam hal ini seyogianya benang kusut pengaturan tata ruang seperti gambar 3 sampai dengan gambar 6 yang telah dipaparkan hendaknya segera dirajut kembali agar hukum tata ruang dapat memberikan kepastian hukum dan menghadirkan rasa keadilan khususnya bagi sektor pertanian yang terusmenerus dikorbankan.

Penerapan teknologi informasi yang dipaparkan dimuka memang bukanlah sesuatu yang diajarkan bagi kalangan hukum pada saat menimba ilmu hukum, tetapi teknologi informasi seyogianya akan menunjang ilmu hukum. Penerapan teknologi informasi perlu dimanfaatkan saat ini. Terlepas dari pro dan kontra, harus diakui bahwa teknologi informasi telah memberikan banyak hal positif bagi masyarakat misalnya melalui startup e-commerce seperti toko online dan transportasi online. Hal ini telah membuka kesempatan kerja bagi masyarakat. Begitu pula perusahaan ekspidisi menjadi semakin marak dan menjanjikan karena banyak orang yang berbelanja online yang sudah barang tentu membutuhkan jasanya untuk mengantarkan barang yang dipesan. Dengan adanya koordinat, pengendara online cukup dengan menekan tombol tertentu di handphone, selanjutnya mereka dapat mengantarkan penumpangnya sesuai tujuan. Seyogianya kemudahan ini dimanfaatkan dengan optimal oleh intelektual di bidang hukum sehingga berbagai aspek dari hukum dapat dijelaskan dengan baik. ${ }^{12}$

Penjabaran sebagian area sebelah barat Meikarta dimuka merupakan sedikit penampakan dari semrawutnya pengaturan rencana tata ruang sehingga berdampak negatif pada lahan pertanian dan petani. Artinya masih banyak kesemrawutan di daerah lainnya dengan pola irisan yang sama sebagaimana telah dipaparkan. Lahan pertanian pangan berkelanjutan berbeda dengan peruntukan pertanian biasa yang dimuat dalam rencana tata ruang. Peruntukan pertanian biasa masih dapat diubah-ubah sesuai keinginan penguasa ${ }^{13}$, akan tetapi lahan pertanian pangan berkelanjutan hanya dapat dialihfungsikan karena "kepentingan umum" dan "bencana". Oleh karena itu kebijakan perlindungan lahan pertanian pangan berkelanjutan mutlak diimplementasikan dan dilaksanakan apabila pemerintah memang serius ingin melindungi lahan pertanian yang tersisa di Indonesia dan sekaligus memberdayakan petani. Untuk memahami konsep dan mengungkap political will pemerintah terhadap kebijakan perlindungan lahan pertanian pangan berkelanjutan maka tulisan ini akan: (1) menjelaskan konsep perlindungan lahan pertanian pangan berkelanjutan dan (2) menganalisis implementasi kebijakan perlindungan lahan pertanian pangan berkelanjutan.

Penelitian ini adalah penelitian hukum normatif dengan menggunakan pendekatan perundang-undangan dan pendekatan analitis. ${ }^{14}$ Data sekunder yang digunakan terdiri dari bahan hukum primer yaitu berupa peraturan-peraturan yang berkaitan dengan bidang penataan ruang. Sedangkan bahan hukum sekunder yang digunakan berupa buku-buku dan jurnal hukum yang berkaitan dengan isu penelitian ini. ${ }^{15}$ Kemudian bahan non hukum berupa buku juga digunakan untuk menunjang penelitian ini.

Mengingat saat ini telah memasuki era revolusi industri 4.0 maka relevan kiranya menganalisis persoalan-persoalan hukum dengan menggunakan teknologi informasi. ${ }^{16}$

\footnotetext{
${ }^{12}$ Satjipto Rahardjo, 2014, Ilmu Hukum, Citra Aditya Bakti, Bandung, hlm. 7.

${ }^{13}$ Lihat Hery Listyawati, Kegagalan Pengendalian Alih Fungsi Tanah dalam Perspektif Penatagunaan Tanah di Indonesia, Jurnal Mimbar Hukum, Vol. 22, No. 1, Edisi Februari 2010, hlm. 49.

${ }^{14}$ Lihat Johnny Ibrahim, 2013, Teori dan Metodologi Penelitian Hukum Normatif, Bayumedia, Malang, hlm. 302 - 306 \& hlm. 310 - 312.

${ }^{15}$ Lihat Soerjono Soekanto, 2015, Pengantar Penelitian Hukum, Penerbit Universitas Indonesia, Jakarta, hlm. 51-52.

${ }^{16}$ Penggunaan teknologi informasi untuk menganalisis persoalan hukum telah dibahas oleh beberapa ahli hukum di Indonesia dan dapat dilihat antara lain dalam buku: Roeslan Saleh, 1983, Jurimetrie Suatu Cara Berfikir dan Berbuat dalam Hukum, Aksara Baru, Jakarta.; Ronny Hanitijo Soemitro, 1990, Metodologi Penelitian Hukum dan Jurimetri, Ghalia Indonesia, Jakarta.; Satjipto Rahardjo, Op. cit., hlm. 357 - 360.; dan Johnny Ibrahim, Loc. cit., hlm. 323 - 343.
} 
Dalam kaitan dengan isu yang diangkat maka penelitian ini akan memanfaatkan tautan http://gistaru.atrbpn.go.id/rtronline/, yang merupakan portal resmi milik pemerintah. Dalam tautan ini telah disajikan secara aktual mengenai informasi peta-peta rencana tata ruang (struktur ruang dan pola ruang) di seluruh Indonesia yang bersumber dari peraturan perundang-undangan yang berlaku di bidang tata ruang. Metode ini perlu diterapkan guna mengungkap fakta sesungguhnya terhadap penentuan atau peletakan rencana tata ruang, terutama yang berkaitan dengan fokus penelitian ini yakni lahan pertanian pangan berkelanjutan. Dengan demikian dapat dikatakan bahwa di era digital saat ini telah hadir semangat keterbukaan informasi di bidang tata ruang sehingga dapat memudahkan peneliti untuk mengetahui apa saja yang dilakukan pemerintah dan pemerintah daerah dalam merencanakan pembangunan di masa mendatang.

\section{PEMBAHASAN}

\section{Konsep Perlindungan Lahan Pertanian Pangan Berkelanjutan}

Berdasarkan Undang-Undang Nomor 41 Tahun 2009 dinyatakan bahwa Lahan Pertanian Pangan Berkelanjutan adalah bidang lahan pertanian yang ditetapkan untuk dilindungi dan dikembangkan secara konsisten guna menghasilkan pangan pokok bagi kemandirian, ketahanan, dan kedaulatan pangan nasional. Kata "dilindungi" sudah barang tentu mempunyai makna bahwa setiap bidang lahan pertanian yang telah "ditetapkan" sebagai Lahan Pertanian Pangan Berkelanjutan tidak boleh dialihfungsikan untuk keperluan nonpertanian oleh siapapun kecuali dalam keadaan tertentu sebagaimana telah disinggung dalam bagian pendahuluan dimuka. Perbuatan atau tindakan apapun yang mengakibatkan terjadinya alih fungsi lahan pertanian pangan berkelanjutan menjadi lahan nonpertanian maka dapat dikenakan sanksi administratif maupun sanksi pidana.

Meskipun terlihat adanya unsur paksaan berupa sanksi namun Undang-Undang Nomor 41 Tahun 2009 memuat juga mekanisme insentif dan disinsentif bagi para petani yang bersedia lahan pertaniannya ditetapkan sebagai Lahan Pertanian Pangan Berkelanjutan. Selain itu, dimuat pula kegiatan pemberdayaan bagi para petani. Kegiatan-kegiatan ini merupakan bentuk perhatian Negara bagi para petani sehingga diharapkan mereka selalu mencintai dan bangga terhadap profesinya dalam sektor pembangunan pertanian, yang pada akhirnya kemandirian, ketahanan dan kedaulatan pangan sebagaimana yang dikehendaki Undang-Undang Nomor 41 Tahun 2009 benarbenar terwujud.

Hal-hal di atas menunjukkan sikap tegas yang dipilih oleh pembuat Undang-Undang Nomor 41 Tahun 2009 dikarenakan mereka memandang perangkat hukum yang ada sebelum terbentuknya undang-undang ini "tidak efektif" mencegah alih fungsi lahan pertanian yang semakin mengkhawatirkan. ${ }^{17}$ Sikap pembentuk undang-undang adalah wajar adanya mengingat pangan (terutama beras) merupakan salah satu kebutuhan mendasar bagi masyarakat Indonesia untuk mempertahankan eksistensinya.

Lebih lanjut ada juga yang berpendapat bahwa Indonesia seyogianya tidak terus bergantung pada pangan impor dari negara lain. Bilamana hal ini dikaitkan dengan keadaan luar negeri seperti Thailand maka perlu menjadi perhatian bagi para pemangku

\footnotetext{
${ }^{17}$ Sekretariat Jenderal Dewan Perwakilan Rakyat Indonesia. Op. cit., hlm. 9-10.
} 
kepentingan. Perlindungan lahan pertanian di Thailand memang jauh lebih baik dari Indonesia, namun generasi muda disana kurang berminat menggeluti sektor pertanian. ${ }^{18}$ Dengan demikian dapat dibayangkan bilamana mereka hanya dapat memenuhi kebutuhan dalam negeri saja dan tidak dapat memenuhi ekspor ke negara lain, maka negara lain yang bergantung pada Thailand akan kekurangan atau kehabisan stok pangan sehingga tidak menutup kemungkinan bencana kelaparan akan terjadi. ${ }^{19}$

Munculnya kebijakan perlindungan lahan pertanian pangan berkelanjutan ditujukan untuk melindungi kawasan dan lahan pertanian pangan secara berkelanjutan; menjamin tersedianya lahan pertanian pangan secara berkelanjutan; mewujudkan kemandirian, ketahanan, dan kedaulatan pangan; melindungi kepemilikan lahan pertanian pangan milik petani; meningkatkan kemakmuran serta kesejahteraan petani dan masyarakat; meningkatkan perlindungan dan pemberdayaan petani; meningkatkan penyediaan lapangan kerja bagi kehidupan yang layak; mempertahankan keseimbangan ekologis; dan mewujudkan revitalisasi pertanian.

Berkenaan dengan perlindungan lahan pertanian pangan berkelanjutan tersebut maka Undang-Undang Nomor 41 Tahun 2009 telah merumuskannya sebagai sistem dan proses dalam merencanakan dan menetapkan, mengembangkan, memanfaatkan dan membina, mengendalikan, dan mengawasi lahan pertanian pangan dan kawasannya secara berkelanjutan. Dari rumusan ini terlihat bahwa sesungguhnya kebijakan tersebut termasuk dalam ruang lingkup hukum administrasi negara sehingga penerapannya sangatlah ditentukan oleh kalangan birokrasi yang berwenang menangani hal ini. Tanpa adanya gerakan yang nyata dari birokrasi maka kebijakan ini tidak dapat berjalan sebagaimana mestinya. Disisi lain dukungan dari para petani juga sangat penting menentukan suksesnya kebijakan ini. Tanpa adanya dukungan para petani maka kebijakan ini hanya angan-angan semata.

Akan tetapi kebijakan perlindungan lahan pertanian pangan berkelanjutan tidak dapat berjalan sebagaimana mestinya bilamana pemerintah belum menetapkan secara pasti dimana letak "Lahan Pertanian Pangan Berkelanjutan" itu berada. Mengenai hal ini, dikatakan oleh pembuat undang-undang bahwa harus dibedakan objek lahan pertanian pangan berkelanjutan dan objek bukan lahan pertanian pangan berkelanjutan. ${ }^{20}$ Dengan demikian kebijakan ini hanya dapat dijalankan pada suatu lahan yang telah ditetapkan sebagai lahan pertanian pangan berkelanjutan. Dengan perkataan lain, kebijakan ini tidak mungkin dilaksanakan pada objek yang bukan lahan pertanian pangan berkelanjutan.

Bila ditelusuri lebih lanjut maka dapat dikatakan bahwa Undang-Undang Nomor 41 Tahun 2009 telah dilengkapi dengan berbagai peraturan pelaksanaanya seperti Peraturan Pemerintah Republik Indonesia Nomor 1 Tahun 2011 tentang Penetapan dan Alih Fungsi Lahan Pertanian Pangan Berkelanjutan; Peraturan Pemerintah Republik Indonesia Nomor 12 Tahun 2012 tentang Insentif Perlindungan Lahan Pertanian Pangan Berkelanjutan; Peraturan Pemerintah Republik Indonesia Nomor 25 Tahun 2012

${ }^{18}$ Lihat Sugama Putra, 2019, Perubahan Alih Fungsi Tanah Pertanian Subak dan Lahan Pertanian Pangan Berkelanjutan di Bali, Fakultas Hukum Universitas Indonesia, Jakarta, Tesis (tidak dipublikasikan), hlm. 178.

${ }^{19}$ Lihat Suparjo Sujadi, Masalah-Masalah Hukum Aktual dalam Wacana Reformasi Agraria di Indonesia, Jurnal Hukum dan Pembangunan, Vol. 37, No. 1, Edisi Januari-Maret 2007, hlm. 94-95. Lihat juga Gatot Irianto, 2016, Lahan dan Kedaulatan Pangan, Gramedia Pustaka Utama, Jakarta, hlm. 2.

${ }^{20}$ Lihat Sekretariat Jenderal Dewan Perwakilan Rakyat Indonesia. Op. cit., hlm. 185.

58 Jurnal IUS Kajian Hukum dan Keadilan 
tentang Sistem Informasi Lahan Pertanian Pangan Berkelanjutan; Peraturan Pemerintah Republik Indonesia Nomor 30 Tahun 2012 tentang Pembiayaan Perlindungan Lahan Pertanian Pangan Berkelanjutan; Peraturan Menteri Pertanian Nomor 07/Permentan/ OT.140/2/2012 tentang Pedoman Teknis Kriteria dan Persyaratan Kawasan, Lahan, dan Lahan Cadangan Pertanian Pangan Berkelanjutan; Peraturan Menteri Pertanian Nomor 79/Permentan/OT.140/8/2013 tentang Pedoman Kesesuaian Lahan Pada Komoditas Tanaman Pangan; Peraturan Menteri Pertanian Nomor 80/Permentan/ OT.140/8/2013 tentang Kriteria dan Tata Cara Penilaian Petani Berprestasi Tinggi Pada Lahan Pertanian Pangan Berkelanjutan; dan Peraturan Menteri Pertanian Nomor 81/Permentan/OT.140/8/2013 tentang Pedoman Teknis Tata Cara Alih Fungsi Lahan Pertanian Pangan Berkelanjutan.

Sehubungan dengan peraturan-peraturan di atas, dapat dikemukakan bahwa peraturan-peraturan tersebut hanya akan menjadi teks-teks yang sama tidak efektifnya dengan perangkat hukum yang lama bilamana letak lahan pertanian pangan pertanian berkelanjutan tidak bisa ditunjukkan keberadaannya.

Dalam perkembangannya masih saja terbit peraturan yang dimaksudkan untuk melindungi lahan pertanian. ${ }^{21}$ Mengenai hal ini, berapa pun banyaknya peraturanperaturan yang akan diterbitkan pemerintah untuk melindungi lahan pertanian, penulis berpendapat bahwa hal itu kiranya akan sia-sia jikalau pemerintah dan pemerintah daerah tidak bisa menunjukkan dimana letak lahan pertanian pangan berkelanjutan berada.

Tampaknya terdapat kesulitan dalam hal menetapkan lahan pertanian pangan berkelanjutan oleh pemerintah. Barangkali persoalan ini dikarenakan semangat UndangUndang Nomor 41 Tahun 2009 yang menganut pendekatan bottom-up ${ }^{22}$ sehingga proses penetapan ini bergantung dari penguasa daerah setempat. Maksud dipergunakannya pendekatan ini sesungguhnya tepat, hal ini agar mampu mengakomodir aspirasi masyarakat setempat. Namun demikian, semenjak diberlakukannya Undang-Undang Nomor 41 Tahun 2009, berapa daerah-kah yang sudah menetapkan lahan pertanian pangan berkelanjutan?

Apabila ditelusuri lebih lanjut maka akan didapatkan beberapa daerah yang telah menetapkan lahan pertanian pangan berkelanjutan melalui peraturan di daerahnya. Pertanyaan selanjutnya apakah dengan adanya peraturan daerah tersebut, daerahdaerah bisa menunjukkan letak lahan pertanian pangan berkelanjutan di daerahnya? Jawabannya sebagian besar daerah tidak bisa menunjukkan letak lahan pertanian pangan berkelanjutan di daerahya, meskipun terdapat luas lahan pertanian pangan berkelanjutan di batang tubuh yang dimuat dalam peraturan daerah. Kenapa demikian? Hal ini dikarenakan peraturan daerah hanya menjabarkan lahan pertanian pangan berkelanjutan dalam pasal-pasalnya saja, namun petanya tidak digambarkan/ didelineasikan lebih lanjut dalam lampiran peta atau bahkan perdanya tidak mempunyai lampiran peta dan kemudian menyerahkan petanya kepada peraturan daerah tentang rencana tata ruang wilayah. Berikut ini akan disajikan tabel daerah-daerah yang telah menetapkan lahan pertanian pangan berkelanjutan dalam Peraturan Daerah tentang Perlindungan Lahan Pertanian Pangan Berkelanjutan.

\footnotetext{
${ }^{21}$ Lihat Peraturan Presiden Nomor 59 Tahun 2019 tentang Pengendalian Alih Fungsi Lahan Sawah.

${ }^{22}$ Lihat Sekretariat Jenderal Dewan Perwakilan Rakyat Indonesia. Op. cit., hlm. 889.
} 
Tabel 1. Lahan Pertanian Pangan Berkelanjutan (LP2B) dalam Peraturan Daerah tentang Perlindungan Lahan Pertanian Pangan Berkelanjutan

$\begin{array}{lccc}\text { No. Nama Daerah } & \text { Peraturan Daerah } & \text { LPa } & \text { Lampiran Peta }\end{array}$

Qanun Kabupaten Aceh
Kabupaten Aceh Be- Besar Nomor 5 Tahun 2013 tentang Perlind- $\quad 33.658$ Tidak Tersedia sar, Provinsi Aceh ungan Lahan Pertanian Pangan Berkelanjutan

\section{Peraturan Dae-}

rah Provinsi Sumatera

2. Provinsi Sumatera Utara Nomor 3 Tahun 2015 tentang Perlind398.913,22 Tidak Tersedia ungan Lahan Pertanian Pangan Berkelanjutan

\begin{tabular}{|c|c|c|c|c|}
\hline 3. & $\begin{array}{l}\text { Kabupaten Batu Bara, } \\
\text { Provinsi Sumatera } \\
\text { Utara }\end{array}$ & $\begin{array}{l}\text { Peraturan Daerah } \\
\text { Kabupaten Batu Bara } \\
\text { Nomor } 10 \text { Tahun } 2014 \\
\text { tentang Perlindungan } \\
\text { Lahan Pertanian Pan- } \\
\text { gan Berkelanjutan }\end{array}$ & Tidak Dimuat & Tidak Tersedia \\
\hline 4. & $\begin{array}{l}\text { Kabupaten Rokan } \\
\text { Hilir, Provinsi Riau }\end{array}$ & $\begin{array}{l}\text { Peraturan Daerah } \\
\text { Kabupaten Rokan Hilir } \\
\text { Nomor } 2 \text { Tahun } 2016 \\
\text { tentang Perlindungan } \\
\text { Lahan Pertanian Pan- } \\
\text { gan Berkelanjutan }\end{array}$ & Tidak Dimuat & Tidak Tersedia \\
\hline 5. & $\begin{array}{l}\text { Kabupaten Bungo, } \\
\text { Provinsi Jambi }\end{array}$ & $\begin{array}{l}\text { Peraturan Daerah Ka- } \\
\text { bupaten Bungo Nomor } \\
7 \text { Tahun } 2014 \text { tentang } \\
\text { Perlindungan Lahan } \\
\text { Pertanian Pangan } \\
\text { Berkelanjutan }\end{array}$ & Tidak Dimuat & Tidak Tersedia \\
\hline 6. & $\begin{array}{l}\text { Kabupaten Batang } \\
\text { Hari, Provinsi Jambi }\end{array}$ & $\begin{array}{l}\text { Peraturan Daerah } \\
\text { Kabupaten Batang Hari } \\
\text { Nomor } 18 \text { Tahun } 2016 \\
\text { tentang Perlindungan } \\
\text { Lahan Pertanian Pan- } \\
\text { gan Berkelanjutan }\end{array}$ & $8.881,46$ & Tidak Tersedia \\
\hline 7. & $\begin{array}{l}\text { Provinsi Sumatera } \\
\text { Selatan }\end{array}$ & $\begin{array}{l}\text { Peraturan Daerah } \\
\text { Provinsi Sumatera Se- } \\
\text { latan Nomor } 21 \text { Tahun } \\
2014 \text { tentang Perlind- } \\
\text { ungan Lahan Pertanian } \\
\text { Pangan Berkelanjutan }\end{array}$ & Tidak Dimuat & Tidak Tersedia \\
\hline
\end{tabular}




\begin{tabular}{|c|c|c|c|c|}
\hline 8. & $\begin{array}{l}\text { Kabupaten Banyuasin, } \\
\text { Provinsi Sumatera } \\
\text { Selatan }\end{array}$ & $\begin{array}{l}\text { Peraturan Daerah } \\
\text { Kabupaten Banyuasin } \\
\text { Nomor } 24 \text { Tahun } 2012 \\
\text { tentang Perlindungan } \\
\text { Lahan Pertanian Pan- } \\
\text { gan Berkelanjutan }\end{array}$ & $232.873,40$ & Tidak Tersedia \\
\hline 9 & Provinsi Lampung & $\begin{array}{l}\text { Peraturan Daerah } \\
\text { Provinsi Lampung No- } \\
\text { mor } 17 \text { Tahun } 2013 \\
\text { tentang Perlindungan } \\
\text { Lahan Pertanian Pan- } \\
\text { gan Berkelanjutan }\end{array}$ & 327.835 & Tidak Tersedia \\
\hline 10. & $\begin{array}{l}\text { Kabupaten Tulang } \\
\text { Bawang, Provinsi } \\
\text { Lampung }\end{array}$ & $\begin{array}{l}\text { Peraturan Dae- } \\
\text { rah Kabupaten Tulang } \\
\text { Bawang Nomor } 2 \\
\text { Tahun } 2016 \text { tentang } \\
\text { Perlindungan Lahan } \\
\text { Pertanian Pangan } \\
\text { Berkelanjutan }\end{array}$ & 31.800 & Tidak Tersedia \\
\hline 11. & $\begin{array}{l}\text { Kabupaten Bangka Se- } \\
\text { latan, Provinsi Bangka } \\
\text { Belitung }\end{array}$ & $\begin{array}{l}\text { Peraturan Daerah Ka- } \\
\text { bupaten Bangka Selatan } \\
\text { Nomor } 3 \text { Tahun } 2016 \\
\text { tentang Perlindungan } \\
\text { Lahan Pertanian Pan- } \\
\text { gan Berkelanjutan }\end{array}$ & $15.869,34$ & Tidak Tersedia \\
\hline 12. & Provinsi Jawa Barat & $\begin{array}{l}\text { Peraturan Daerah } \\
\text { Provinsi Jawa Barat } \\
\text { Nomor } 27 \text { Tahun } 2010 \\
\text { tentang Perlindungan } \\
\text { Lahan Pertanian Pan- } \\
\text { gan Berkelanjutan }\end{array}$ & Tidak Dimuat & Tidak Tersedia \\
\hline 13. & $\begin{array}{l}\text { Kabupaten Indramayu, } \\
\text { Provinsi Jawa Barat }\end{array}$ & $\begin{array}{l}\text { Peraturan Daerah } \\
\text { Kabupaten Indramayu } \\
\text { Nomor } 16 \text { Tahun } 2013 \\
\text { tentang Perlindungan } \\
\text { Lahan Pertanian Pan- } \\
\text { gan Berkelanjutan }\end{array}$ & Tidak Dimuat & Tidak Tersedia \\
\hline 14. & $\begin{array}{l}\text { Kabupaten Kuningan, } \\
\text { Provinsi Jawa Barat }\end{array}$ & $\begin{array}{l}\text { Peraturan Daerah } \\
\text { Kabupaten Kuningan } \\
\text { Nomor } 7 \text { Tahun } 2015 \\
\text { tentang Perlindun- } \\
\text { gan Lahan Pertanian } \\
\text { Pangan Berkelanjutan } \\
\text { Kabupaten Kuningan }\end{array}$ & Tidak Dimuat & Tidak Tersedia \\
\hline
\end{tabular}




\begin{tabular}{|c|c|c|c|c|}
\hline 15. & $\begin{array}{l}\text { Kota Sukabumi, } \\
\text { Provinsi Jawa Barat }\end{array}$ & $\begin{array}{l}\text { Peraturan Daerah Kota } \\
\text { Sukabumi Nomor } 1 \\
\text { Tahun } 2016 \text { tentang } \\
\text { Perlindungan Lahan } \\
\text { Pertanian Pangan } \\
\text { Berkelanjutan }\end{array}$ & Tidak Dimuat & Tidak Tersedia \\
\hline 16. & $\begin{array}{l}\text { Kabupaten Garut, } \\
\text { Provinsi Jawa Barat }\end{array}$ & $\begin{array}{l}\text { Peraturan Daerah Ka- } \\
\text { bupaten Garut Nomor } \\
3 \text { Tahun } 2016 \text { tentang } \\
\text { Lahan Pertanian Pan- } \\
\text { gan Berkelanjutan Pada } \\
\text { Pusat Kegiatan Lokal } \\
\text { Perkotaan Garut di } \\
\text { Kabupaten Garut }\end{array}$ & 1.437 & $\begin{array}{l}\text { Tersedia sesuai } \\
\text { dengan Pasal } 4 \\
\text { ayat (4) }\end{array}$ \\
\hline 17. & $\begin{array}{l}\text { Kabupaten Tasikma- } \\
\text { laya, Provinsi Jawa } \\
\text { Barat }\end{array}$ & $\begin{array}{l}\text { Peraturan Daerah Ka- } \\
\text { bupaten Tasikmalaya } \\
\text { Nomor } 4 \text { Tahun } 2016 \\
\text { tentang Perlindungan } \\
\text { Lahan Pertanian Pan- } \\
\text { gan Berkelanjutan }\end{array}$ & Tidak Dimuat & Tidak Tersedia \\
\hline 18. & Provinsi Jawa Tengah & $\begin{array}{l}\text { Peraturan Daerah } \\
\text { Provinsi Jawa Tengah } \\
\text { Nomor } 2 \text { Tahun } 2013 \\
\text { tentang Perlindun- } \\
\text { gan Lahan Pertanian } \\
\text { Pangan Berkelanjutan } \\
\text { Provinsi Jawa Tengah }\end{array}$ & Tidak Dimuat & Tidak Tersedia \\
\hline 19. & $\begin{array}{l}\text { Kabupaten Teman- } \\
\text { ggung, Provinsi Jawa } \\
\text { Tengah }\end{array}$ & $\begin{array}{l}\text { Peraturan Daerah Ka- } \\
\text { bupaten Temanggung } \\
\text { Nomor } 2 \text { Tahun } 2014 \\
\text { tentang Perlindungan } \\
\text { Lahan Pertanian Pan- } \\
\text { gan Berkelanjutan jo. } \\
\text { Peraturan Daerah Ka- } \\
\text { bupaten Temanggung } \\
\text { Nomor } 4 \text { Tahun } 2017 \\
\text { tentang Perubahan } \\
\text { atas Peraturan Daerah } \\
\text { Kabupaten Teman- } \\
\text { ggung Nomor } 2 \text { Tahun } \\
\text { 2014 tentang Perlind- } \\
\text { ungan Lahan Pertanian } \\
\text { Pangan }\end{array}$ & 20.709 & $\begin{array}{l}\text { Tersedia sesuai } \\
\text { dengan Pasal } 7\end{array}$ \\
\hline 20. & $\begin{array}{l}\text { Kabupaten Jepara, } \\
\text { Provinsi Jawa Tengah }\end{array}$ & $\begin{array}{l}\text { Peraturan Daerah Ka- } \\
\text { bupaten Jepara Nomor } \\
4 \text { Tahun } 2014 \text { tentang } \\
\text { Perlindungan Lahan } \\
\text { Pertanian Pangan } \\
\text { Berkelanjutan }\end{array}$ & Tidak Dimuat & Tidak Tersedia \\
\hline
\end{tabular}




\begin{tabular}{|c|c|c|c|c|}
\hline 21. & $\begin{array}{l}\text { Kabupaten Boyolali, } \\
\text { Provinsi Jawa Tengah }\end{array}$ & $\begin{array}{l}\text { Peraturan Daerah } \\
\text { Kabupaten Boyolali } \\
\text { Nomor } 17 \text { Tahun } 2016 \\
\text { tentang Perlindungan } \\
\text { Lahan Pertanian Pan- } \\
\text { gan Berkelanjutan }\end{array}$ & $16.500,99$ & $\begin{array}{c}\text { Tersedia sesuai } \\
\text { dengan Pasal } 9 \\
\text { ayat (3) }\end{array}$ \\
\hline 22. & Provinsi Banten & $\begin{array}{l}\text { Peraturan Daerah } \\
\text { Provinsi Banten Nomor } \\
5 \text { Tahun } 2014 \text { tentang } \\
\text { Perlindungan Lahan } \\
\text { Pertanian Pangan } \\
\text { Berkelanjutan }\end{array}$ & $169.515,47$ & Tidak Tersedia \\
\hline 23. & $\begin{array}{l}\text { Kabupaten Lebak, } \\
\text { Provinsi Banten }\end{array}$ & $\begin{array}{l}\text { Peraturan Daerah Ka- } \\
\text { bupaten Lebak Nomor } \\
3 \text { Tahun } 2016 \text { tentang } \\
\text { Perlindungan Lahan } \\
\text { Pertanian Pangan } \\
\text { Berkelanjutan }\end{array}$ & Tidak Dimuat & Tidak Tersedia \\
\hline 24. & $\begin{array}{l}\text { Kabupaten Bangkalan, } \\
\text { Provinsi Jawa Timur }\end{array}$ & $\begin{array}{l}\text { Peraturan Daerah } \\
\text { Kabupaten Bangkalan } \\
\text { Nomor } 5 \text { Tahun } 2013 \\
\text { tentang Perlindungan } \\
\text { Lahan Pertanian Pan- } \\
\text { gan Berkelanjutan }\end{array}$ & 30.002 & Tidak Tersedia \\
\hline 25. & $\begin{array}{l}\text { Kabupaten Madiun, } \\
\text { Provinsi Jawa Timur }\end{array}$ & $\begin{array}{l}\text { Peraturan Daerah } \\
\text { Kabupaten Madiun No- } \\
\text { mor } 1 \text { Tahun } 2014 \text { ten- } \\
\text { tang Lahan Pertanian } \\
\text { Pangan Berkelanjutan } \\
\text { Kabupaten Madiun }\end{array}$ & 21.587 & Tidak Tersedia \\
\hline 26. & $\begin{array}{l}\text { Kabupaten Gresik, } \\
\text { Provinsi Jawa Timur }\end{array}$ & $\begin{array}{l}\text { Peraturan Daerah Ka- } \\
\text { bupaten Gresik Nomor } \\
7 \text { Tahun } 2015 \text { tentang } \\
\text { Perlindungan Lahan } \\
\text { Pertanian Pangan } \\
\text { Berkelanjutan }\end{array}$ & 24.716 & $\begin{array}{c}\text { Tersedia sesuai } \\
\text { dengan Pasal } 8 \\
\text { ayat (6) }\end{array}$ \\
\hline 27. & $\begin{array}{l}\text { Kabupaten Proboling- } \\
\text { go, Provinsi Jawa } \\
\text { Timur }\end{array}$ & $\begin{array}{l}\text { Peraturan Daerah } \\
\text { Kabupaten Probolinggo } \\
\text { Nomor } 10 \text { Tahun } 2015 \\
\text { tentang Perlindungan } \\
\text { Lahan Pertanian Pan- } \\
\text { gan Berkelanjutan }\end{array}$ & 38.692 & Tidak Tersedia \\
\hline
\end{tabular}




\begin{tabular}{|c|c|c|c|c|}
\hline 28. & $\begin{array}{l}\text { Kabupaten Treng- } \\
\text { galek, Provinsi Jawa } \\
\text { Timur }\end{array}$ & $\begin{array}{l}\text { Peraturan Daerah } \\
\text { Kabupaten Trenggalek } \\
\text { Nomor } 2 \text { Tahun } 2016 \\
\text { tentang Perlindungan } \\
\text { Lahan Pertanian Pan- } \\
\text { gan Berkelanjutan }\end{array}$ & 12.785 & Tidak Tersedia \\
\hline 29. & $\begin{array}{l}\text { Kabupaten Situbondo, } \\
\text { Provinsi Jawa Timur }\end{array}$ & $\begin{array}{l}\text { Peraturan Daerah } \\
\text { Kabupaten Situbondo } \\
\text { Nomor } 4 \text { Tahun } 2017 \\
\text { tentang Perlindungan } \\
\text { Lahan Pertanian Pan- } \\
\text { gan Berkelanjutan }\end{array}$ & 30.032 & Tidak Tersedia \\
\hline 30. & $\begin{array}{l}\text { Provinsi Daerah Is- } \\
\text { timewa Yogyakarta }\end{array}$ & $\begin{array}{l}\text { Peraturan Daerah } \\
\text { Provinsi Daerah Istime- } \\
\text { wa Yogyakarta Nomor } \\
10 \text { Tahun } 2011 \text { tentang } \\
\text { Perlindungan Lahan } \\
\text { Pertanian Pangan } \\
\text { Berkelanjutan }\end{array}$ & $35.911,59$ & Tidak Tersedia \\
\hline 31. & $\begin{array}{l}\text { Kabupaten Gunung } \\
\text { Kidul, Provinsi Daerah } \\
\text { Istimewa Yogyakarta }\end{array}$ & $\begin{array}{l}\text { Peraturan Daerah Ka- } \\
\text { bupaten Gunung Kidul } \\
\text { Nomor } 14 \text { Tahun } 2012 \\
\text { tentang Perlindungan } \\
\text { Lahan Pertanian Pan- } \\
\text { gan Berkelanjutan }\end{array}$ & 5.505 & Tidak Tersedia \\
\hline 32. & $\begin{array}{l}\text { Kabupaten Jembrana, } \\
\text { Provinsi Bali }\end{array}$ & $\begin{array}{l}\text { Peraturan Daerah } \\
\text { Kabupaten Jembrana } \\
\text { Nomor } 5 \text { Tahun } 2015 \\
\text { tentang Perlindungan } \\
\text { Lahan Pertanian Pan- } \\
\text { gan Berkelanjutan }\end{array}$ & $7.498,12$ & Tidak Tersedia \\
\hline 33. & $\begin{array}{l}\text { Provinsi Nusa Teng- } \\
\text { gara Barat }\end{array}$ & $\begin{array}{l}\text { Peraturan Daerah } \\
\text { Provinsi Nusa Tenggara } \\
\text { Barat Nomor } 1 \text { Tahun } \\
2013 \text { tentang Perlind- } \\
\text { ungan Lahan Pertanian } \\
\text { Pangan Berkelanjutan } \\
\text { jo. Peraturan Daerah } \\
\text { Provinsi Nusa Tenggara } \\
\text { Barat Nomor } 10 \text { Tahun } \\
2017 \text { tentang Peru- } \\
\text { bahan atas Peraturan } \\
\text { Daerah Provinsi Nusa } \\
\text { Tenggara Barat Nomor } \\
1 \text { Tahun 2013 tentang } \\
\text { Perlindungan Lahan } \\
\text { Pertanian Pangan } \\
\text { Berkelanjutan }\end{array}$ & 227.606 & Tidak Tersedia \\
\hline
\end{tabular}




\begin{tabular}{|c|c|c|c|c|}
\hline 34. & $\begin{array}{l}\text { Kabupaten Sekadau, } \\
\text { Provinsi Kalimantan } \\
\text { Barat }\end{array}$ & $\begin{array}{l}\text { Peraturan Daerah } \\
\text { Kabupaten Sekadau } \\
\text { Nomor } 9 \text { Tahun } 2014 \\
\text { tentang Perlindungan } \\
\text { Lahan Pertanian Pan- } \\
\text { gan Berkelanjutan }\end{array}$ & 26.605 & Tidak Tersedia \\
\hline 35. & $\begin{array}{l}\text { Kabupaten Sanggau, } \\
\text { Provinsi Kalimantan } \\
\text { Barat }\end{array}$ & $\begin{array}{l}\text { Peraturan Daerah } \\
\text { Kabupaten Sanggau } \\
\text { Nomor } 2 \text { Tahun } 2015 \\
\text { tentang Perlindungan } \\
\text { Lahan Pertanian Pan- } \\
\text { gan Berkelanjutan }\end{array}$ & Tidak Dimuat & Tidak Tersedia \\
\hline 36. & $\begin{array}{l}\text { Provinsi Kalimantan } \\
\text { Selatan }\end{array}$ & $\begin{array}{l}\text { Peraturan Daerah } \\
\text { Provinsi Kalimantan } \\
\text { Selatan Nomor } 2 \\
\text { Tahun } 2014 \text { tentang } \\
\text { Perlindungan Lahan } \\
\text { Pertanian Tanaman } \\
\text { Pangan Berkelanjutan }\end{array}$ & 353.803 & Tidak Tersedia \\
\hline 37. & $\begin{array}{l}\text { Kabupaten Banjar, } \\
\text { Provinsi Kalimantan } \\
\text { Selatan }\end{array}$ & $\begin{array}{l}\text { Peraturan Daerah Ka- } \\
\text { bupaten Banjar Nomor } \\
9 \text { Tahun } 2012 \text { tentang } \\
\text { Perlindungan Lahan } \\
\text { Pertanian Pangan } \\
\text { Berkelanjutan }\end{array}$ & Tidak Dimuat & Tidak Tersedia \\
\hline 38. & $\begin{array}{l}\text { Kabupaten Balangan, } \\
\text { Provinsi Kalimantan } \\
\text { Selatan }\end{array}$ & $\begin{array}{l}\text { Peraturan Daerah } \\
\text { Kabupaten Balangan } \\
\text { Nomor } 20 \text { Tahun } 2014 \\
\text { tentang Perlindungan } \\
\text { Lahan Pertanian Pan- } \\
\text { gan Berkelanjutan }\end{array}$ & Tidak Dimuat & Tidak Tersedia \\
\hline 39. & $\begin{array}{l}\text { Kota Banjarmasin, } \\
\text { Provinsi Kalimantan } \\
\text { Selatan }\end{array}$ & $\begin{array}{l}\text { Peraturan Daerah Kota } \\
\text { Banjarmasin Nomor } \\
12 \text { Tahun } 2015 \text { tentang } \\
\text { Perlindungan Lahan } \\
\text { Pertanian Pangan } \\
\text { Berkelanjutan }\end{array}$ & Tidak Dimuat & Tidak Tersedia \\
\hline 40. & $\begin{array}{l}\text { Provinsi Kalimantan } \\
\text { Timur }\end{array}$ & $\begin{array}{l}\text { Peraturan Daerah } \\
\text { Provinsi Kalimantan } \\
\text { Timur Nomor } 1 \text { Tahun } \\
2013 \text { tentang Perlind- } \\
\text { ungan Lahan Pertanian } \\
\text { Pangan Berkelanjutan }\end{array}$ & 1.916 .643 & Tidak Tersedia \\
\hline
\end{tabular}




\begin{tabular}{|c|c|c|c|c|}
\hline 41. & $\begin{array}{l}\text { Kabupaten Kutai } \\
\text { Kartanegara, Provinsi } \\
\text { Kalimantan Timur }\end{array}$ & $\begin{array}{l}\text { Peraturan Daerah Ka- } \\
\text { bupaten Kutai Kartane- } \\
\text { gara Nomor } 3 \text { Tahun } \\
2012 \text { tentang Perlind- } \\
\text { ungan Lahan Pertanian } \\
\text { Pangan Berkelanjutan }\end{array}$ & Tidak Dimuat & Tidak Tersedia \\
\hline 42. & $\begin{array}{l}\text { Kabupaten Malinau, } \\
\text { Provinsi Kalimantan } \\
\text { Utara }\end{array}$ & $\begin{array}{l}\text { Peraturan Daerah } \\
\text { Kabupaten Malinau } \\
\text { Nomor } 8 \text { Tahun } 2014 \\
\text { tentang Perlindungan } \\
\text { Lahan Pertanian Pan- } \\
\text { gan Berkelanjutan }\end{array}$ & 3.916 & Tidak Tersedia \\
\hline 43. & $\begin{array}{l}\text { Provinsi Sulawesi } \\
\text { Tengah }\end{array}$ & $\begin{array}{l}\text { Peraturan Daerah } \\
\text { Provinsi Sulawesi } \\
\text { Tengah Nomor } 1 \\
\text { Tahun } 2015 \text { tentang } \\
\text { Perlindungan Lahan } \\
\text { Pertanian Pangan } \\
\text { Berkelanjutan }\end{array}$ & 119.702 & Tidak Tersedia \\
\hline 44. & $\begin{array}{l}\text { Kabupaten Tojo Una- } \\
\text { Una, Provinsi Sulawe- } \\
\text { si Tengah }\end{array}$ & $\begin{array}{l}\text { Peraturan Dae- } \\
\text { rah Kabupaten Tojo } \\
\text { Una-Una Nomor } 6 \\
\text { Tahun } 2016 \text { tentang } \\
\text { Perlindungan Lahan } \\
\text { Pertanian Pangan } \\
\text { Berkelanjutan }\end{array}$ & 5.113 & Tidak Tersedia \\
\hline 45. & $\begin{array}{l}\text { Provinsi Sulawesi } \\
\text { Selatan }\end{array}$ & $\begin{array}{l}\text { Peraturan Daerah } \\
\text { Provinsi Sulawesi } \\
\text { Selatan Nomor } 4 \\
\text { Tahun } 2014 \text { tentang } \\
\text { Perlindungan Lahan } \\
\text { Pertanian Pangan } \\
\text { Berkelanjutan }\end{array}$ & Tidak Dimuat & Tidak Tersedia \\
\hline 46. & $\begin{array}{l}\text { Kabupaten Luwu Ut- } \\
\text { ara, Provinsi Sulawesi } \\
\text { Selatan }\end{array}$ & $\begin{array}{l}\text { Peraturan Daerah } \\
\text { Kabupaten Luwu } \\
\text { Utara Nomor } 8 \\
\text { Tahun } 2015 \text { tentang } \\
\text { Perlindungan Lahan } \\
\text { Pertanian Pangan } \\
\text { Berkelanjutan }\end{array}$ & Tidak Dimuat & Tidak Tersedia \\
\hline
\end{tabular}




\begin{tabular}{|c|c|c|c|c|}
\hline 47. & $\begin{array}{l}\text { Kota Kendari, Provinsi } \\
\text { Sulawesi Tenggara }\end{array}$ & $\begin{array}{l}\text { Peraturan Daerah } \\
\text { Kota Kendari Nomor } \\
9 \text { Tahun } 2015 \text { tentang } \\
\text { Perlindungan Lahan } \\
\text { Pertanian Pangan } \\
\text { Berkelanjutan }\end{array}$ & Tidak Dimuat & Tidak Tersedia \\
\hline 48. & Provinsi Gorontalo & $\begin{array}{l}\text { Peraturan Daerah } \\
\text { Provinsi Gorontalo } \\
\text { Nomor } 1 \text { Tahun } 2014 \\
\text { tentang Perlindungan } \\
\text { Lahan Pertanian Pan- } \\
\text { gan Berkelanjutan }\end{array}$ & Tidak Dimuat & Tidak Tersedia \\
\hline 49. & $\begin{array}{l}\text { Kabupaten Bone Bol- } \\
\text { ango, Provinsi Goron- } \\
\text { talo }\end{array}$ & $\begin{array}{l}\text { Peraturan Daerah } \\
\text { Kabupaten Bone } \\
\text { Bolango Nomor } 11 \\
\text { Tahun } 2014 \text { tentang } \\
\text { Perlindungan Lahan } \\
\text { Pertanian Pangan } \\
\text { Berkelanjutan }\end{array}$ & 2.046 & Tidak Tersedia \\
\hline 50. & $\begin{array}{l}\text { Kabupaten Gorontalo, } \\
\text { Provinsi Gorontalo }\end{array}$ & $\begin{array}{l}\text { Peraturan Daerah } \\
\text { Kabupaten Gorontalo } \\
\text { Nomor } 2 \text { Tahun } 2017 \\
\text { tentang Perlindungan } \\
\text { Lahan Pertanian Pan- } \\
\text { gan Berkelanjutan }\end{array}$ & Tidak Dimuat & Tidak Tersedia \\
\hline 51. & Provinsi Papua & $\begin{array}{l}\text { Peraturan Daerah } \\
\text { Provinsi Papua No- } \\
\text { mor } 27 \text { Tahun } 2013 \\
\text { tentang Perlindungan } \\
\text { Lahan Pertanian Pan- } \\
\text { gan Pokok Berkelan- } \\
\text { jutan }\end{array}$ & 2.071.199 & $\begin{array}{c}\text { Tersedia sesuai } \\
\text { dengan Pasal } 14 \\
\text { ayat (3) }\end{array}$ \\
\hline
\end{tabular}

Dari paparan tabel 1 di atas, terlihat keberagaman pengaturan lahan pertanian pangan berkelanjutan dalam peraturan daerah. Ada daerah yang mencantumkan luas lahan pertanian pangan berkelanjutan dalam batang tubuh pasal, ada pula daerah yang tidak mencantumkan luas. Begitu pula dengan lampiran peta, ada yang melampirkan dan ada yang tidak mempunyai lampiran peta. Bagi daerah yang tidak mempunyai lampiran peta, terdapat ketentuan pasal yang menentukan bahwa lahan pertanian pangan berkelanjutan ditetapkan dalam peraturan daerah tentang rencana tata ruang wilayah. Mengenai hal ini, kiranya relevan diberikan contoh peraturan daerah yang menyerahkan penetapan lahan pertanian pangan berkelanjutan pada rencana tata ruang wilayahnya seperti di Provinsi Daerah Istimewa Yogyakarta.

Dalam Pasal 9 ayat (1) Peraturan Provinsi Daerah Istimewa Yogyakarta Nomor 10 Tahun 2011 tentang Perlindungan Lahan Pertanian Pangan Berkelanjutan dinyatakan 
bahwa "Lahan Pertanian Pangan berkelanjutan yang ditetapkan dalam Rencana Tata Ruang dan Wilayah Daerah ditetapkan dengan luas paling kurang 35.911,59 Hektar". Selanjutnya dapat dilihat pula penjabarannya dalam tingkat peraturan daerah kabupaten/ kota. Dalam hal ini Pasal 10 ayat (1) Peraturan Daerah Kabupaten Gunungkidul Nomor 23 Tahun 2012 tentang Perlindungan Lahan Pertanian Pangan Berkelanjutan menegaskan bahwa "Penetapan Kawasan Pertanian Pangan Berkelanjutan merupakan bagian dari penetapan rencana tata ruang Kawasan Perdesaan di wilayah Daerah dalam rencana tata ruang Daerah sesuai dengan ketentuan peraturan perundang-undangan". Apakah benar Provinsi Daerah Istimewa Yogyakarta dan Kabupaten Gunungkidul terdapat lahan pertanian pangan berkelanjutan? Sudah barang tentu untuk menjawab pertanyaan ini perlu melihat peraturan daerah tentang rencana tata ruang wilayah setempat, terutama lampiran petanya.

Saat ini lampiran peta rencana tata ruang wilayah di seluruh Indonesia dapat diakses dengan mudah pada portal resmi Pemerintah melalui tautan http://gistaru.atrbpn.go.id/ rtronline/. Dengan memanfaatkan portal ini dapat dipastikan bahwa Provinsi Daerah Istimewa Yogyakarta dan Kabupaten Gunungkidul tidak terdapat Lahan Pertanian Pangan Berkelanjutan, baik itu dalam Peraturan Daerah Provinsi Daerah Istimewa Yogyakarta Nomor 2 Tahun 2010 tentang Rencana Tata Ruang Wilayah Provinsi Daerah Istimewa Yogyakarta Tahun 2009 - 2029, maupun Peraturan Daerah Kabupaten Gunungkidul Nomor 6 Tahun 2011 tentang Rencana Tata Ruang Wilayah Kabupaten Gunungkidul Tahun 2010 - 2030. Dalam kata lain, daerah ini hanyalah mempunyai teks-teks peraturan semata yang tak dapat diterapkan dilapangan sehingga kemudian berimplikasi pada lajunya alih fungsi lahan pertanian.

Oleh karena itu seyogianya debottlenecking terhadap lajunya alih fungsi tanah pertanian di negara ini hanya bisa dijawab dengan kepastian peta yang di dalamnya terdapat koordinat-koordinat yang dapat menunjukkan letak lahan pertanian pangan berkelanjutan secara pasti. Dengan demikian "peta" yang lazimnya diletakan dalam lampiran suatu peraturan sangatlah berperan penting. Peta yang dimuat dalam lampiran suatu peraturan merupakan produk hukum karena sudah barang tentu selalu dinyatakan bahwa lampiran (termasuk lampiran peta) merupakan bagian tidak terpisahkan dari suatu peraturan.

Sebagaimana telah disinggung dimuka bahwa Undang-Undang Nomor 41 Tahun 2009 adalah produk hukum penjabaran dari undang-undang penataan ruang. Sudah sepantasnya suatu undang-undang pelaksanaan dari undang-undang lain, tidak terlepas dari peraturan induknya. Dalam hal ini kiranya Undang-Undang Nomor 41 Tahun 2009 tidak dapat berdiri sendiri dalam merealisasikan tujuannya karena bergantung dari dukungan undang-undang penataan ruang. Oleh karenanya, pembahasan ini perlu juga membahas dukungan undang-undang penataan ruang terhadap kebijakan perlindungan lahan pertanian pangan berkelanjutan.

\section{Implementasi Kebijakan Perlindungan Lahan Pertanian Pangan Berkelanjutan}

Sebelum membahas lebih lanjut uraian ini, perlu ditegaskan kembali bahwa tulisan ini bertolak dari asumsi bahwa hukum sebagai produk politik. Hukum yang dimaksudkan disini adalah hukum negara atau peraturan perundang-undangan berbentuk tertulis. Sudut pandang ini sangat penting diutarakan sebab sebagaimana telah disinggung bahwa kebijakan perlindungan lahan pertanian pangan berkelanjutan berada dalam lingkup hukum administrasi negara. Menurut beberapa pihak, hukum administrasi negara tidak memberi tempat pada hukum yang tidak tertulis. Dengan perkataan lain, hukum 
administrasi negara hanya memberi tempat bagi hukum berbentuk tertulis. ${ }^{23}$ Dalam kaitan hal ini maka hukum yang tertulis itu ditentukan oleh politik. Bilamana hukum tertulis tersebut tidak lengkap menjabarkan mekanisme dan prosedur suatu persoalan yang ingin dipecahkan maka sudah dapat ditebak bahwa masalah itu tidak akan bisa diselesaikan.

Memang harus diakui bahwa kebijakan perlindungan lahan pertanian pangan berkelanjutan sangat ditentukan oleh rencana tata ruang. Rencana tata ruang ibarat motor penggerak bagi keberhasilan sektor pertanian dan juga semua sektor sumber daya alam di Indonesia. Namun isu yang selalu mengemuka yaitu sukarnya mengalokasikan sumber daya ruang yang terbatas secara seimbang sehingga pada titik inilah sering terjadi konflik kepentingan. ${ }^{24}$

Beberapa kalangan hukum telah mengemukakan pandangannya mengenai tujuan sesungguhnya yang diharapkan dari pengaturan tata ruang. Mengenai hal ini dikatakan bahwa ruang perlu dikelola secara berkelanjutan untuk sebesar-besar kemakmuran rakyat. Dengan perkataan lain bahwa Undang-Undang Penataan Ruang berpihak pada perlindungan kepentingan rakyat. ${ }^{25}$ Penataan ruang diharapkan dapat mengalokasikan ruang bagi kegiatan semua kelompok masyarakat untuk kesejahteraan mereka semua dan menyisakan sebagian lainnya untuk generasi yang akan datang. ${ }^{26}$ Menyimak hal ini dapat dikatakan bahwa penataan ruang termasuk pula ke dalam arena diskursus mengenai keadilan. Pemerhati hukum tata ruang lainnya berpendapat bahwa penataan ruang merupakan cetak biru yang memberikan arahan (as a guidelines) terhadap aktifitas penguasaan, penggunaan dan pemanfaatan tanah bagi berbagai kepentingan oleh subjek hak agar tidak merugikan kepentingan masyarakat, menjaga agar tidak terjadi degradasi kualitas tanah serta terjaminnya kepastian hukum atas bidang tanah yang bersangkutan. ${ }^{27}$ Para pemerhati hukum agraria ini sesungguhnya mendambakan semangat nilai kearifan tradisional sebagai dasar penyusunan tata ruang sehingga tata ruang benar-benar berjalan pada relnya untuk sebesar-besar kemakmuran rakyat.

Hal menarik lainnya dari pengaturan tata ruang yaitu kemampuannya yang bisa mewujudkan suatu area tertentu menjadi jauh lebih baik daripada area yang tidak direncanakan sebelumnya. Bumi Serpong Damai (BSD) merupakan salah satu contoh planning dari kota yang direncanakan sebelum penduduknya masuk ke dalam ruang tersebut. ${ }^{28}$ Akan tetapi pengaturan tata ruang yang sarat kepentingan tertentu juga dapat berdampak negatif bagi masyarakat setempat. Sebagai contoh, dahulu sebagian besar Kawasan Industri Pulogadung merupakan lahan pertanian subur tetapi saat ini telah berubah manjadi pabrik-pabrik. Dalam upaya melancarkan keingginan untuk memperoleh lahan sawah subur itu, terkadang pihak pemilik pabrik menjanjikan akan mempekerjakan bekas pemilik lahan dipabriknya, namun janji tersebut jarang ditepati karena profesi petani tidak memenuhi kualifikasi dan syarat yang ditentukan. ${ }^{29}$ Dengan demikian para petani yang semula beraktifitas menggarap lahan sawah untuk menghasilkan pangan bagi dirinya dan masyarakat, telah berubah pola kehidupannya.

\footnotetext{
${ }^{23}$ Lihat Peter Mahmud Marzuki, 2014, Pengantar Ilmu Hukum, Kencana, Jakarta, hlm. 184. Lihat juga Sri Hajati, Ellyne Dwi Poespasari \& Oemar Moechthar, 2017, Pengantar Hukum Indonesia, Airlangga University Press, Surabaya, hlm. 14.

${ }^{24}$ Imam Koeswahyono, 2012, Hukum Penatagunaan Tanah dan Penataan Ruang di Indonesia (Problematika antara Teks dan Konteks), Universitas Brawijaya Press, Malang, hlm. 11.

${ }^{25}$ Maria S.W. Sumardjono, et al., 2014, Pengaturan Sumber Daya Alam di Indonesia, Antara yang Tersurat dan Tersirat: Kajian Kritis Undang-Undang Terkait Penataan Ruang dan Sumber Daya Alam, Gadjah Mada University Press, Yogyakarta, hlm. 175.

${ }^{26}$ Nurhasan Ismail, 2018, Hukum Agraria dalam Tantangan Perubahan, Setara Press, Malang, hlm. 213.

${ }^{27}$ Imam Koeswahyono, Op. cit., hlm. 54.

${ }^{28}$ Bambang Prabowo Soedarso, 2008, Penataan Ruang, Pemanfaatan, Akibat dan Pertanggungjawaban Hukum Negara, Cintya Press, Jakarta, hlm. 4.

${ }^{29}$ Ibid., hlm. 15.
} 
Perubahan pola kehidupan petani itu bisa saja menjadikannya lebih baik, namun bisa pula menjadikannya makin terpuruk.

Menyimak penjabaran di atas tampak bahwa adanya hubungan yang erat antara pengaturan tata ruang dengan lahan yang diaturnya. Dalam konteks pengaturan lahan, para pemerhati agraria lainnya juga mendambakan pembaharuan hukum tanah untuk memberikan perlindungan hukum bagi rakyat banyak, terutama golongan petani. ${ }^{30}$ Begitu pula diharapkan hukum tanah ke depan dapat menjadi pelindung bagi kepentingan rakyat yang tidak berdaya karena berbagai kelemahan dan keterbelakangannya seperti petani dan masyarakat hukum adat. ${ }^{31}$ Sejalan dengan hal ini dikatakan juga bahwa pemerintah berkewajiban menjamin dan melindungi hak hak tanah bagi petani. ${ }^{32}$ Dengan demikian dapat ditarik simpulan bahwa pengaturan tata ruang yang ideal adalah pengaturan tata ruang yang bisa mengalokasikan sumber daya ruang secara proporsional yang tentunya berlaku juga terhadap sektor pertanian, yang mana dalam sektor ini terdapat masyarakat marjinal yang perlu dilindungi oleh negara.

Berkenaan dengan uraian di atas maka perlu kiranya melihat sampai sejauh manakah kebijakan perlindungan lahan pertanian pangan berkelanjutan itu telah diimplementasikan dalam sistem hukum penataan ruang. Oleh karenanya berikut ini akan disajikan daerah-daerah mana saja yang telah mengintegrasikan lahan pertanian pangan berkelanjutan dalam rencana tata ruang wilayah.

Tabel 2. Lahan Pertanian Pangan Berkelanjutan Dalam Rencana Tata Ruang Wilayah

\begin{tabular}{|c|c|c|c|}
\hline No. & Nama Daerah & Peraturan Daerah & $\begin{array}{c}\text { Keterangan } \\
\text { Rencana Pola Ruang }\end{array}$ \\
\hline 1. & $\begin{array}{l}\text { Kabupaten Aceh Jaya, } \\
\text { Provinsi Aceh }\end{array}$ & $\begin{array}{l}\text { Qanun Kabupaten Aceh } \\
\text { Jaya Nomor } 9 \text { Tahun } 2014\end{array}$ & PLP2B \\
\hline 2. & $\begin{array}{l}\text { Kabupaten Aceh Tamiang, } \\
\text { Provinsi Aceh }\end{array}$ & $\begin{array}{l}\text { Qanun Kabupaten Aceh } \\
\text { Tamiang } 14 \text { Tahun } 2013\end{array}$ & PLPPB \\
\hline 3. & $\begin{array}{l}\text { Kota Serang, Provinsi } \\
\text { Banten }\end{array}$ & $\begin{array}{l}\text { Peraturan Daerah Kota } \\
\text { Serang Nomor } 6 \text { Tahun } \\
2011\end{array}$ & $\begin{array}{l}\text { Kawasan Pertanian } \\
\text { Pangan Berkelanjutan }\end{array}$ \\
\hline 4. & $\begin{array}{l}\text { Kabupaten Purwakarta, } \\
\text { Provinsi Jawa Barat }\end{array}$ & $\begin{array}{l}\text { Peraturan Daerah Kabu- } \\
\text { paten Purwakarta Nomor } 11 \\
\text { Tahun } 2012\end{array}$ & $\begin{array}{l}\text { Kawasan Peruntukkan } \\
\text { Budidaya Tanaman } \\
\text { Pangan (LP2B) }\end{array}$ \\
\hline 5. & $\begin{array}{l}\text { Kabupaten Bandung Barat, } \\
\text { Provinsi Jawa Barat }\end{array}$ & $\begin{array}{l}\text { Peraturan Daerah Kabu- } \\
\text { paten Bandung Barat No. } 2 \\
\text { Tahun } 2012\end{array}$ & $\begin{array}{l}\text { Tanaman Pangan } \\
\text { Berkelanjutan }\end{array}$ \\
\hline 6. & $\begin{array}{l}\text { Kabupaten Purbalingga, } \\
\text { Provinsi Jawa Tengah }\end{array}$ & $\begin{array}{l}\text { Peraturan Daerah Kabu- } \\
\text { paten Purbalingga Nomor } 5 \\
\text { Tahun } 2011\end{array}$ & $\begin{array}{l}\text { Tanaman Pangan } \\
\text { Berkelanjutan }\end{array}$ \\
\hline 7. & $\begin{array}{l}\text { Kabupaten Kudus, Provinsi } \\
\text { Jawa Tengah }\end{array}$ & $\begin{array}{l}\text { Peraturan Daerah Kabupat- } \\
\text { en Kudus Nomor } 16 \text { Tahun } \\
2012\end{array}$ & $\begin{array}{ll}\text { - } & \text { Kawasan Pertanian } \\
\text { Tanaman Pangan } \\
\text { ditetapkan sebagai } \\
\text { LP2B } \\
\text { - } \quad \text { Lahan Cadangan } \\
\text { P2B } \\
\end{array}$ \\
\hline
\end{tabular}

\footnotetext{
${ }^{30}$ Boedi Harsono, 2013, Menuju Penyempurnaan Hukum Tanah Nasional, Penerbit Universitas Trisakti, Jakarta, hlm. 4.

${ }^{31}$ Achmad Sodiki, 2013, Politik Hukum Agraria, Konstitusi Press, Jakarta, hlm. 194.

${ }^{32}$ Soedjarwo Soeromihardjo, 2009, Mengkritisi Undang-Undang Pokok Agraria, Cerdas Pustaka, Jakarta, hlm. 15.
} 


\begin{tabular}{|c|c|c|c|}
\hline 8. & $\begin{array}{l}\text { Kabupaten Tulungagung, } \\
\text { Provinsi Jawa Timur }\end{array}$ & $\begin{array}{l}\text { Peraturan Daerah Kabu- } \\
\text { paten Tulungagung Nomor } \\
11 \text { Tahun } 2012\end{array}$ & $\begin{array}{l}\text { Lahan Pertanian Pan- } \\
\text { gan Berkelanjutan }\end{array}$ \\
\hline 9. & $\begin{array}{l}\text { Kabupaten Lumajang, } \\
\text { Provinsi Jawa Timur }\end{array}$ & $\begin{array}{l}\text { Peraturan Daerah Kabu- } \\
\text { paten Lumajang Nomor } 2 \\
\text { Tahun } 2013\end{array}$ & $\begin{array}{l}\text { Rencana Kaw. Perta- } \\
\text { nian Berkelanjutan }\end{array}$ \\
\hline 10. & $\begin{array}{l}\text { Kabupaten Probolinggo, } \\
\text { Provinsi Jawa Timur }\end{array}$ & $\begin{array}{l}\text { Peraturan Daerah Kabu- } \\
\text { paten Probolinggo Nomor } 3 \\
\text { Tahun } 2011\end{array}$ & $\begin{array}{l}\text { Lahan Pertanian Pan- } \\
\text { gan Berkelanjutan }\end{array}$ \\
\hline 11. & $\begin{array}{l}\text { Kabupaten Mojokerto, } \\
\text { Provinsi Jawa Timur }\end{array}$ & $\begin{array}{l}\text { Peraturan Daerah Kabu- } \\
\text { paten Mojokerto Nomor } 9 \\
\text { Tahun } 2012\end{array}$ & LP2B \\
\hline 12. & $\begin{array}{l}\text { Kabupaten Tuban, Provinsi } \\
\text { Jawa Timur }\end{array}$ & $\begin{array}{l}\text { Peraturan Daerah Kabupat- } \\
\text { en Tuban Nomor } 9 \text { Tahun } \\
2012\end{array}$ & $\begin{array}{l}\text { Lahan Pertanian Pan- } \\
\text { gan Berkelanjutan }\end{array}$ \\
\hline 13. & $\begin{array}{l}\text { Kabupaten Lamongan, } \\
\text { Provinsi Jawa Timur }\end{array}$ & $\begin{array}{l}\text { Peraturan Daerah Kabu- } \\
\text { paten Lamongan Nomor } 15 \\
\text { Tahun } 2011\end{array}$ & $\begin{array}{l}\text { Lahan Pertanian } \\
\text { Berkelanjutan }\end{array}$ \\
\hline 14. & $\begin{array}{l}\text { Kota Kediri, Provinsi Jawa } \\
\text { Timur }\end{array}$ & $\begin{array}{l}\text { Peraturan Daerah Kota } \\
\text { Kediri Nomor } 1 \text { Tahun } 2012\end{array}$ & $\begin{array}{l}\text { Lahan Pertanian Pan- } \\
\text { gan Berkelanjutan }\end{array}$ \\
\hline 15. & $\begin{array}{l}\text { Kabupaten Banjar, Provinsi } \\
\text { Kalimantan Selatan }\end{array}$ & $\begin{array}{l}\text { Peraturan Daerah Kabupat- } \\
\text { en Banjar Nomor } 3 \text { Tahun } \\
2013\end{array}$ & $\begin{array}{l}\text { Pertanian Pangan } \\
\text { Berkelanjutan }\end{array}$ \\
\hline 16. & $\begin{array}{l}\text { Kabupaten Hulu Sungai Se- } \\
\text { latan, Provinsi Kalimantan } \\
\text { Selatan }\end{array}$ & $\begin{array}{l}\text { Peraturan Daerah Kabu- } \\
\text { paten Hulu Sungai Selatan } \\
\text { Nomor } 3 \text { Tahun } 2014\end{array}$ & $\begin{array}{l}\text { Kawasan Pertanian } \\
\text { Lahan Abadi }\end{array}$ \\
\hline 17. & $\begin{array}{l}\text { Kabupaten Tanah Bumbu, } \\
\text { Provinsi Kalimantan Sela- } \\
\text { tan }\end{array}$ & $\begin{array}{l}\text { Peraturan Daerah Kabu- } \\
\text { paten Tanah Bumbu Nomor } \\
5 \text { Tahun } 2017\end{array}$ & $\begin{array}{l}\text { Kawasan Pertanian } \\
\text { Pangan Berkelanjutan }\end{array}$ \\
\hline 18. & $\begin{array}{l}\text { Kota Banjarmasin, Provinsi } \\
\text { Kalimantan Selatan }\end{array}$ & $\begin{array}{l}\text { Peraturan Daerah Kota Ban- } \\
\text { jarmasin Nomor } 5 \text { Tahun } \\
2013\end{array}$ & $\begin{array}{l}\text { Pertanian Berkelanju- } \\
\text { tan }\end{array}$ \\
\hline 19. & $\begin{array}{l}\text { Kabupaten Sukamara, } \\
\text { Provinsi Kalimantan Ten- } \\
\text { gah }\end{array}$ & $\begin{array}{l}\text { Peraturan Daerah Kabu- } \\
\text { paten Sukamara Nomor } 14 \\
\text { Tahun } 2012\end{array}$ & $\begin{array}{l}\text { Pertanian Pangan } \\
\text { Berkelanjutan }\end{array}$ \\
\hline 20. & $\begin{array}{l}\text { Kabupaten Bulungan, } \\
\text { Provinsi Kalimantan Utara }\end{array}$ & $\begin{array}{l}\text { Peraturan Daerah Kabu- } \\
\text { paten Bulungan Nomor } 4 \\
\text { Tahun } 2013\end{array}$ & $\begin{array}{l}\text { Kawasan LP2B dan } \\
\text { Pencadangan LP2B }\end{array}$ \\
\hline 21. & $\begin{array}{l}\text { Kabupaten Tulang Bawang } \\
\text { Barat, Provinsi Lampung }\end{array}$ & $\begin{array}{l}\text { Peraturan Daerah Kabu- } \\
\text { paten Tulang Bawang Barat } \\
\text { Nomor } 2 \text { Tahun } 2012\end{array}$ & $\begin{array}{ll}- & \text { Kawasan Perta- } \\
& \text { nian Lahan Kering } \\
\text { Berkelanjutan } \\
\text { - } & \text { Kawasan Pertanian } \\
& \text { Pangan Berkelan- } \\
& \text { jutan } \\
\end{array}$ \\
\hline 22. & $\begin{array}{l}\text { Kabupaten Sumba Tengah, } \\
\text { Provinsi Nusa Tenggara } \\
\text { Timur }\end{array}$ & $\begin{array}{l}\text { Peraturan Daerah Kabupat- } \\
\text { en Sumba Tengah Nomor } 1 \\
\text { Tahun } 2011\end{array}$ & $\begin{array}{l}\text { Lahan Pertanian Pangan } \\
\text { Berkelanjutan }\end{array}$ \\
\hline
\end{tabular}


23. Kabupaten Biak Numfor Darat, Provinsi Papua

Peraturan Daerah Kabupaten Biak Numfor Nomor 11 Tahun 2011

Peraturan Daerah Kabu-

24. Kabupaten Donggala, Provinsi Sulawesi Tengah

25. Kabupaten Tojo Una-Una, Provinsi Sulawesi Tengah paten Donggala Nomor 1 Tahun 2011

Peraturan Daerah Kabupaten Tojo Una-Una Nomor 8 Tahun 2012
Tanaman Pangan

(Berkelanjutan)

Lahan Pertanian Pangan

Berkelanjutan

Lahan Pertanian

Berkelanjutan

Sumber: http://gistaru.atrbpn.go.id/rtronline/, diakses pada tanggal 21 Oktober 2019.

Setelah menyimak tabel 2 di atas, terlihat bahwa terdapat 25 kabupaten/kota dari total 514 kabupaten/kota di Indonesia yang sudah memuat lahan pertanian pangan berkelanjutan dalam rencana tata ruangnya. Hal ini merupakan indikator yang sangat penting untuk menyatakan bahwa sampai tulisan ini dipublikasikan, kebijakan perlindungan lahan pertanian pangan berkelanjutan kurang di dukung oleh rencana tata ruang di daerah. Sebagaimana diketahui bahwa rencana tata ruang dibuat oleh pemerintah atau pemerintah daerah sesuai dengan kewenangan yang diberikan UndangUndang Penataan Ruang. Dalam hal rencana tata ruang yang dipaparkan dalam tabel di atas, dapat dikemukakan bahwa kewenangan itu berada pada daerah kabupaten/kota. Dengan demikian dapat disimpulkan bahwa ada permasalahan lemahnya political will penguasa-penguasa daerah dalam upaya mewujudkan kebijakan perlindungan lahan pertanian pangan berkelanjutan di Indonesia.

Begitu pula jika dilihat dari peraturan daerah provinsi mengenai rencana tata ruang wilayah maka tidak ada satu pun provinsi di Indonesia yang telah memuat lahan pertanian pangan berkelanjutan dalam rencana tata ruang tingkat provinsi. Mengenai hal ini maka ada baiknya disajikan perbandingan persentase antara peraturan daerah provinsi dan peraturan daerah kabupaten/kota terkait isu yang diajukan.

Tabel 3. Persentase Rencana Tata Ruang Tingkat Provinsi dan Kabupaten/Kota Yang Memuat Lahan Pertanian Pangan Berkelanjutan

\begin{tabular}{llccr} 
No. & \multicolumn{1}{c}{ Jenis Peraturan } & $\begin{array}{c}\text { Jumlah } \\
\text { Daerah }\end{array}$ & $\begin{array}{c}\text { Pola Ruang } \\
\text { LP2B }\end{array}$ & Persentase \\
\hline 1. & Peraturan Daerah Provinsi & 34 & 0 & $0,00 \%$ \\
\hline $\begin{array}{l}\text { 2. } \\
\quad \text { peraturan Daerah Kabu- }\end{array}$ & 514 & 25 & $4,86 \%$ \\
\hline
\end{tabular}

Diolah dan bersumber dari: http://gistaru.atrbpn.go.id/rtronline/, diakses pada tanggal 21

Oktober 2019.

Berpegang pada apa yang disajikan tabel 3 di atas, teranglah bahwa kebijakan perlindungan lahan pertanian pangan berkelanjutan saling menunggu untuk diimplementasikan dalam peraturan yang lebih tinggi dari peraturan daerah kabupaten/ kota. Hal ini memang sesuai dengan ide pembentuk undang-undang tersebut yang berkehendak menggunakan pendekatan bottom-up terhadap perangkat peraturan ini. Dapat dikemukakan pula bahwa terdapat permasalahan lemahnya political will 
penguasa-penguasa daerah karena belum serius mendukung penuh kebijakan ini sehingga Undang-Undang Nomor 41 Tahun 2009 belum dapat bekerja sebagaimana yang diharapkan.

Pada tataran pemerintah pusat sesungguhnya telah terdapat arahan dalam Peraturan Pemerintah Nomor 13 Tahun 2017 yang memuat peruntukan pertanian seluas 77.410 kilo meter persegi yang tersebar di seluruh Indonesia. Seyogianya apa yang diarahkan oleh peraturan pemerintah ini ditindaklanjuti oleh daerah-daerah dengan menyelaraskannya dengan peraturan daerahnya masing-masing. Peruntukan pertanian yang selaras irisannya dari level peraturan tinggi ke level peraturan rendah seyogianya dijadikan sebagai lahan pertanian pangan berkelanjutan. Jika tidak segera ditindaklanjuti maka luas peruntukan pertanian yang dinyatakan oleh peraturan pemerintah itu akan terus berkurang sehingga cita-cita pemerintah untuk mewujudkan kemandirian, ketahanan, dan kedaulatan pangan akan terganggu. Namun demikian hal ini perlu di dukung oleh kekuatan politik penguasa daerah yang sungguh-sungguh ingin mewujudkan tujuan yang dikehendaki oleh Undang-Undang Nomor 41 Tahun 2009, tanpa adanya dukungan itu maka kebijakan ini niscaya akan sulit untuk direalisasikan.

\section{SIMPULAN}

Pertama, konsep perlindungan lahan pertanian pangan berkelanjutan bertujuan mewujudkan kemandirian, ketahanan, dan kedaulatan pangan yang dilengkapi dengan unsur pemaksa berupa sanksi bagi siapa saja yang berani mengalihfungsikannya menjadi lahan nonpertanian. Selain itu kebijakan ini berbicara insentif dan disinsentif bagi para petani. Akan tetapi kebijakan tersebut tidak dapat berdiri sendiri karena sangat bergantung pada dukungan peraturan di bidang penataan ruang. Kedua, implementasi kebijakan perlindungan lahan pertanian pangan berkelanjutan di Indonesia yang dimuat dalam peraturan daerah mengenai rencana tata ruang masih sangat rendah dikarenakan berbagai faktor yang mempengaruhinya terutama faktor politik penguasa daerah yang kurang peduli dengan kebijakan ini. Sementara itu gerakan ditingkat pusat sudah menunjukkan arahan untuk mendorong kembali kebijakan ini. Hal ini dapat dilihat dalam Peraturan Pemerintah Nomor 13 Tahun 2017, yang mana antara lain memuat peruntukan pertanian seluas 77.410 kilo meter persegi. Oleh karena itu perlu adanya dorongan lain yaitu sistem sanksi pengurangan anggaran bagi daerah-daerah yang tidak patuh pada arahan Peraturan Pemerintah Nomor 13 Tahun 2017.

\section{DAFTAR PUSTAKA}

\section{Buku}

Hajati, Sri, Ellyne Dwi Poespasari \& Oemar Moechthar, (2017), Pengantar Hukum Indonesia, Airlangga University Press, Surabaya.

Harsono, Boedi, (2013), Menuju Penyempurnaan Hukum Tanah Nasional, Penerbit Universitas Trisakti, Jakarta.

Ibrahim, Johnny, (2013), Teori dan Metodologi Penelitian Hukum Normatif, Bayumedia, Malang.

Irianto, Gatot, (2016), Lahan dan Kedaulatan Pangan, Gramedia Pustaka Utama, Jakarta.

Ismail, Nurhasan, (2018), Hukum Agraria dalam Tantangan Perubahan, Setara Press, Malang. 
Koeswahyono, Imam, (2012), Hukum Penatagunaan Tanah dan Penataan Ruang di Indonesia (Problematika antara Teks dan Konteks), Universitas Brawijaya Press, Malang.

Marzuki, Peter Mahmud, (2014), Pengantar Ilmu Hukum, Kencana, Jakarta.

Prabowo Soedarso, Bambang, (2008), Penataan Ruang, Pemanfaatan, Akibat dan Pertanggungjawaban Hukum Negara, Cintya Press, Jakarta.

Rahardjo, Satjipto, (2014), Пmu Hukum, Citra Aditya Bakti, Bandung.

Saleh, Roeslan, (1983), Jurimetrie Suatu Cara Berfikir dan Berbuat dalam Hukum, Aksara Baru, Jakarta.

Sekretariat Jenderal Dewan Perwakilan Rakyat Indonesia, (2012), Proses Pembahasan Rancangan Undang-Undang tentang Perlindungan Lahan Pertanian Pangan Berkelanjutan Buku 1. SekretariatJenderal Dewan Perwakilan Rakyat Indonesia, Jakarta.

Sodiki, Achmad, (2013), Politik Hukum Agraria, Konstitusi Press, Jakarta.

Soekanto, Soerjono, (2015), Pengantar Penelitian Hukum, Penerbit Universitas Indonesia, Jakarta.

Soemitro, Ronny Hanitijo, (1990), Metodologi Penelitian Hukum dan Jurimetri, Ghalia Indonesia, Jakarta.

Soeprapto, Maria Farida Indrati, (1998), Пmu Perundang-Undangan, Penerbit Kanisius, Yogyakarta.

Soeromihardjo, Soedjarwo, (2009), Mengkritisi Undang-Undang Pokok Agraria, Cerdas Pustaka, Jakarta.

Sumardjono, Maria S.W., (2009), Tanah Dalam Perspektif Hak Ekonomi, Sosial dan Budaya, Penerbit Buku Kompas, Jakarta.

Sumardjono, Maria S.W. et al., (2014), Pengaturan Sumber Daya Alam di Indonesia, Antara yang Tersurat dan Tersirat: Kajian Kritis Undang-Undang Terkait Penataan Ruang dan Sumber Daya Alam, Gadjah Mada University Press, Yogyakarta.

\section{Tesis}

Putra, Sugama, (2019). Perubahan Alih Fungsi Tanah Pertanian Subak dan Lahan Pertanian Pangan Berkelanjutan di Bali, Tesis (tidak dipublikasikan), Fakultas Hukum Universitas Indonesia, Jakarta.

\section{Jurnal}

Listyawati, Hery, Kegagalan Pengendalian Alih Fungsi Tanah dalam Perspektif Penatagunaan Tanah di Indonesia, Jurnal Mimbar Hukum, Vol. 22, No. 1, Edisi Februari 2010, 37-57.

Sujadi, Suparjo, Masalah-Masalah Hukum Aktual dalam Wacana Reformasi Agraria di Indonesia, Jurnal Hukum dan Pembangunan, Vol. 37, No. 1, Edisi Januari-Maret 2007, 90-118.

\section{Peraturan Perundang-Undangan}

Undang-Undang Nomor 26 Tahun 2007 tentang Penataan Ruang (Lembaran Negara 
Tahun 2007 Nomor 68, Tambahan Lembaran Negara Nomor 4725).

Undang-Undang Nomor 41 Tahun 2009 tentang Perlindungan Lahan Pertanian Pangan Berkelanjutan (Lembaran Negara Tahun 2009 Nomor 149, Tambahan Lembaran Negara Nomor 5068).

Undang-Undang Nomor 12 Tahun 2011 tentang Pembentukan Peraturan PerundangUndangan (Lembaran Negara Tahun 2011 Nomor 82, Tambahan Lembaran Negara Nomor 5234).

Peraturan Pemerintah Nomor 13 Tahun 2017 tentang Perubahan Atas Peraturan Pemerintah Nomor 26 Tahun 2008 tentang Rencana Tata Ruang Wilayah Nasional (Lembaran Negara Tahun 2017 Nomor 77, Tambahan Lembaran Negara Nomor 6042).

Peraturan Presiden Nomor 59 Tahun 2019 tentang Pengendalian Alih Fungsi Lahan Sawah (Lembaran Negara Tahun 2019 Nomor 163).

\section{Website}

Amalo, Palce, "Pemprov NTT Ancam Gusur Perumahan di Lahan Pertanian." https:// www.mediaindonesia.com/read/detail/257772-pemprov-ntt-ancam-gusurperumahan-di-lahan-pertanian, diakses pada tanggal 10 Oktober 2019.

Andryandy, Tommi, "Raperda Dibekukan, Potensi Alih Fungsi di Kabupaten Bekasi Makin Terbuka." https://www.pikiran-rakyat.com/jawa-barat/2019/07/23/ raperda-dibekukan-potensi-alih-fungsi-di-kabupaten-bekasi-makin-terbuka, diakses pada tanggal 10 Oktober 2019.

Kompas, "Mengkhawatirkan! Alih Fungsi Lahan Pertanian." https://nasional.kompas. $\mathrm{com} / \mathrm{read} / 2009 / 06 / 08 / 09585932 /$ mengkhawatirkan.alih.fungsi.lahan. pertanian, diakses pada tanggal 10 Oktober 2019 .

Setiawan, Silvy Dian, "Alih Fungsi Lahan di DIY Capai 250 Hektare per Tahun.” https:// www.republika.co.id/berita/nasional/daerah/19/03/13/poasot370-alih-fungsilahan-di-diy-capai-250-hektare-per-tahun, diakses pada tanggal 10 Oktober 2019.

WH, Anton, "Revisi LP2B Tak Matikan Pertanian." https:/www.suaramerdeka.com/ smcetak/baca/83750/revisi-lp2b-tak-matikan-pertanian, diakses pada tanggal 10 Oktober 2019. 
Jurnal IUS Kajian Hukum dan Keadilan | Vol VIII | Nomor 1 | April 2020 | hlm, 76 76 